\title{
RAGE Signaling in Melanoma Tumors
}

\author{
Olamide T. Olaoba $\mathbb{D}^{0}$, Sultan Kadasah, Stefan W. Vetter $(\mathbb{D}$ and Estelle Leclerc *
}

Department of Pharmaceutical Sciences, School of Pharmacy, North Dakota State University, Fargo, ND 58105, USA; olaobamide@gmail.com (O.T.O.); sultan.kadasah@ndsu.edu (S.K.); Stefan.Vetter@ndsu.edu (S.W.V.)

* Correspondence: estelle.leclerc@ndsu.edu; Tel.: +1-701-231-5187

Received: 30 October 2020; Accepted: 23 November 2020; Published: 26 November 2020

\begin{abstract}
Despite recent progresses in its treatment, malignant cutaneous melanoma remains a cancer with very poor prognosis. Emerging evidences suggest that the receptor for advance glycation end products (RAGE) plays a key role in melanoma progression through its activation in both cancer and stromal cells. In tumors, RAGE activation is fueled by numerous ligands, S100B and HMGB1 being the most notable, but the role of many other ligands is not well understood and should not be underappreciated. Here, we provide a review of the current role of RAGE in melanoma and conclude that targeting RAGE in melanoma could be an approach to improve the outcomes of melanoma patients.
\end{abstract}

Keywords: melanoma; RAGE; receptor for advanced glycation end products; S100 proteins; HMGB1; inflammation; tumorigenesis; melanomagenesis

\section{Melanoma}

Melanoma originates from the abnormal growth of melanocytes, and it can become very invasive and aggressive [1]. Despite being relatively rare among cutaneous cancers $(<5 \%)$, melanoma is the leading cause of skin cancer-related mortality [2,3]. Melanocytes are part of a complex of three cell types that constitute the keratinocyte, Langerhans cells, and melanocyte (KLM) unit of the epidermis, and they are critical for melanin production [4]. Melanocytes synthesize melanin within special organelles called melanosomes. Melanin production is a process that is regulated by UV radiation, synthesis of the melanocyte stimulating hormone (MSH) and increased expression of its receptor, the melanocortin 1 receptor (MC1-R). A key enzyme in the synthesis of melanin pigments is tyrosinase [5]. Upon melanin synthesis, the melanosomes are transferred to keratinocytes through the help of dendrites [4]. In the skin, melanin has a protective role and provides a photo shielding effect against DNA-damaging UV radiation. Additionally, melanin has chemoprevention, thermoregulation, and metal-chelating properties [5]. In the skin and other tissues, the loss of melanocytes is associated with pathological consequences $[4,6]$.

\subsection{Driver Mutations in Melanomagenesis}

Melanomagenesis is the result of genetic and epigenetic modifications, as well as alterations in signaling pathways controlling key cellular functions. Next-generation sequencing analysis of 686 cutaneous melanoma tissues revealed key genes in melanomagenesis [7]. Three important pathways contributing to melanomagenesis were found to be the cyclin-dependent kinase inhibitor $2 \mathrm{~A}$ (CDKN2A) pathway, the mitogen-activated protein kinase (MAPK) pathway including neuroblastoma RAS viral oncogene homolog (NRAS) and V-raf murine sarcoma viral oncogene homolog B1 (BRAF), as well as the phosphatidylinositol-3 kinase (PI3K)/AKT/mammalian target of rapamycin (mTOR) pathway [7-9]. In this large study, the most frequent alterations were found in BRAF (49.6\%) and RAS $(29.4 \%)$, with $94 \%$ RAS mutations being in NRAS. In addition to these two main melanoma driver 
genes, other driver genes were identified and classified into three groups based on their mutation prevalence. The first group contained genes that were found mutated in 10 to $20 \%$ of melanoma tissues and included CDKN2A, neurofibromatosis type1 (NF1), AT-rich interactive domain-containing protein 2 (ARID2), and tumor protein p53 (TP53). The second group comprised of serine/threonine-protein phosphatase 6 catalytic subunit (PPP6C), DEAD-box helicase 3 X-linked (DDX3X), phosphatase and tension homology (PTEN), and ras-related C3 botulinum toxin substrate 1 (RAC1) genes, which showed mutations in 5 to $9 \%$ melanoma tissues. F-box/WD repeat-containing protein 7 (FBXW7), sorting nexin 31 (SNX31), phosphatidylinositol-3,4,5- trisphosphate-dependent rac exchange factor 2 (PREX2), MAPK1-2, transforming acidic coiled-coil-containing protein 1 (TACC1), KIT tyrosine protein kinase (KIT), isocitrate dehydrogenase1. (IDH1), retinoblastoma protein 1 (RB1), splicing factor $3 \mathrm{~b}$ subunit 1 (SF3B1), catenin (cadherin-associate protein) beta 1 (CTNMB1), PIK3 catalytic subunit alpha (PI3KCA), cyclin-dependent kinase 4 (CDK4), ras p21 protein activator 2 (RASA2), Wilms' tumor suppressor gene 1 (WT1), enhancer of zeste homolog 2 (EZH2), and serine/threonine-protein kinase 19 (STK19) genes constituted the third group, and mutations in these genes were less frequently detected $(<5 \%)$. It was also observed that $6.6 \%$ of cutaneous melanoma tissues were negative for any genetic modification [7]. This study supported the current concept that the mutational landscape of genes in melanomas is unparalleled, and thus, it results in large molecular heterogeneity.

\subsection{Cutaneous and Non-Cutaneous Melanoma}

Although most melanoma tumors develop in the skin (cutaneous melanoma), they can also arise in mucosal membranes, [10-17], in the eye (uveal melanoma) [18], and primary melanoma tumors have also been described in leptomeninges (Table 1) [19]. Among these different types of melanoma, cutaneous melanoma is by far the most prevalent. For instance, the histopathological diagnosis of malignant melanoma in India during a period of 5 years showed that $93.4 \%$ of the cases were cutaneous melanoma, whereas only $6.6 \%$ non-cutaneous melanoma were characterized in conjunctiva, anorectum, gingiva-buccal sulcus, vagina, palate, and the nasal cavity [20]. Although cutaneous melanoma has a higher likelihood in Caucasians than in other ethnicities, mucosal melanoma incidence is not race dependent [21]. Features such as the etiology, pathogenesis, epidemiology, prognosis, clinical course, and frequency of genetic alterations further distinguish mucosal melanoma from its cutaneous counterpart [22,23]. Mucosal melanoma is frequently present in the head and neck region (55.4\% all cases), vulvovaginal area (18\%), and anal/rectal region $(23.8 \%)$, and it can be found in the urinary tract as well (2.8\%) [23-25]. In ocular melanoma, the most common sites for melanoma are the posterior uvea, affecting the ciliary body and choroid [26]. However, melanoma in the conjunctiva, orbit, retina, vitreous, iris, and the anterior chamber of the eye have also been reported [27]. The other non-cutaneous melanoma, such as the poorly prognosed leptomeningeal melanoma may emerge from severe neurocutaneous melanocytosis [19]. Cutaneous melanoma can be classified in four major groups according to histopathological features: superficial spreading melanoma (SSM), nodular, lentigo, and acral lentigious melanomas [28]. SSM is the most common group and accounts for $70 \%$ of all cutaneous melanoma cases. 
Table 1. Different types and groups of melanoma.

\begin{tabular}{|c|c|c|c|c|}
\hline Melanoma & \multicolumn{4}{|c|}{ Types and Groups } \\
\hline Cutaneous & \multicolumn{4}{|c|}{$\begin{array}{ll}\text { - } & \text { Superficial spreading melanoma } \\
\text { - } & \text { Nodular melanoma } \\
\text { - } & \text { Lentigo malignant melanoma } \\
\text { - } & \text { Acral lentiginous melanoma }\end{array}$} \\
\hline \multirow{4}{*}{ Extra-cutaneous } & Mucosal & \multicolumn{3}{|c|}{$\begin{array}{ll}\text { - } & \text { Head and neck } \\
\text { - } & \text { Vulvovaginal } \\
\text { - } & \text { Anorectal }\end{array}$} \\
\hline & \multirow[t]{2}{*}{ Ocular } & Uveal tract & & $\begin{array}{l}\text { Choroid } \\
\text { Iris } \\
\text { Ciliary }\end{array}$ \\
\hline & & \multicolumn{3}{|c|}{ Conjunctiva } \\
\hline & Leptomeningeal & \multicolumn{3}{|c|}{$\begin{array}{ll}\text { - } & \text { Benign melanocytoma } \\
\text { - } & \text { Malignant melanoma }\end{array}$} \\
\hline
\end{tabular}

\subsection{Staging of Melanoma and Patient Survival}

The staging system of melanoma established by the American Joint Commission in Cancer (AJCC) was recently revised and updated [29]. This system is based on four pathological stage groupings (I to IV) and different factors such as the primary tumor thickness and volume, whether the tumor is ulcerated or has reached the nearby lymph nodes, the presence of distant metastases, or the mitotic index of tumors $[29,30]$.

Among the four types of melanoma (cutaneous, mucosal, ocular, and leptomeningeal), staging is less difficult with cutaneous melanoma than non-cutaneous ones because of the presence of tumors on the skin. For similar reasons, patient survival is higher in this type of melanoma than in the non-cutaneous counterparts because of earlier diagnosis. For instance, a recent meta-analysis showed a 2.25-fold higher lethality in mucosal than in cutaneous melanoma [31]. The overall survival (OS) and disease-specific survival (DSS) in melanoma patients depends on many factors including tumor stage, histology, type of treatment the patient is receiving, as well as age [32]. Overall, metastatic melanoma is very aggressive and poorly controlled; it is associated with low OS, usually between 6 and 9 months [33].

\subsection{Melanoma Biomarkers}

A biomarker (molecule) is a molecule that can be measured in tissues, blood, and other body fluids and is an indicator of a disease [34]. Biomarkers can be used for diagnostic or prognosis purposes. Diagnostic biomarkers are present in higher levels in diseased patients than healthy patients. Prognostic or predictive markers have increased expression in advanced stages of the disease or different expression during treatment and can indicate potential recurrence of the disease [34]. Although several molecules have some potential clinical values as melanoma biomarkers (lactate dehydrogenase (LDH), tyrosinase, Programmed Cell Death 1 Ligand 1 (PD1L1) and S100B), they also presented some limitations, and for this reason, there is currently no ideal biomarker in melanoma [35-38]. Here, we will just briefly discuss the strengths and limitations of these four molecules with potential clinical values. LDH is probably the strongest independent prognostic and main serum biomarker for clinical use in metastatic cancer patients [39-41]. LDH catalyzes the conversion of pyruvate into lactate, which is a reaction that occurs when oxidative phosphorylation is impaired, such as observed in cancer tumors through a process described as the Warburg effect [42]. This process is further enhanced in hypoxic regions of solid tumors due to poor vascularization and supplied oxygen, and it is observed in melanoma tumors [43,44]. In metastatic melanoma patients, elevated levels of serum LDH, measured 
using its enzymatic activity, correlate with low overall survival [45] and also appear to be strongly predictive of overall survival following immunotherapy with the current standards of care ipilimubab, pembrolizumab, and nivolumab [46,47]. However, elevated levels of LDH are not specific to melanoma tumors and are also observed in other diseased tissues [48].

Tyrosinase is another molecule with clinical value in melanoma. Tyrosinase is an enzyme that participates in the synthesis of melanin pigments in melanocytes and melanoma. In melanoma patients, serum levels of circulating tyrosinase mRNA transcripts have been evaluated as a prognostic marker: high expression levels are associated with poor prognosis $[35,49,50]$. However, a large variability has been observed between studies due in part to the transient presence of melanoma tumor cells in the blood stream and to non-standardized protocols when performing polymerase chain (PCR) reaction experiments [51].

Another molecule with potential clinical value is PD1L1, the ligand activating Programmed Cell Death Receptor 1 (PD-1) [52]. PD1L1 is a cell surface transmembrane protein expressed by tumor cells and can also occur in a soluble form as result of alternate splicing or proteolysis. PD-1 is a cell surface receptor expressed by immune cells ( $\mathrm{T}$ and $\mathrm{B}$ cells, macrophages) that transmits apoptotic or activation signals, resulting in either the suppression or activation of immune cells. In cytotoxic $\mathrm{T}$ cells, the PD-1/PD1L1 axis acts as a switch that turns off cytotoxic T-cell activation, resulting in tumor cells that are capable of evading immune surveillance [53]. High levels of PD1L1 are found in certain types of cancer, including melanoma [53,54]. Expression levels of PD1L1 in tumor biopsies are thought to predict the response levels of melanoma patients to treatment with immune checkpoint inhibitors, such as nivolumab and pembrolizumab (PD-1 antibodies) [55,56]. However, there are some limitations regarding the use of PD1L1 levels as biomarkers for immunotherapy. These limitations reside in the heterogeneity of PD1L1 expression in melanoma tumors [57] and the observation that even patients carrying melanoma tumors with a low expression of PD1L1 have shown benefits from immunotherapy [58,59].

S100B has clinical value as a prognostic biomarker of treatment response. S100B is a small EF-hand calcium binding protein that is expressed by melanocytes and released in the extracellular milieu by melanoma tumors [60]. Inside cells, S100B interacts with the transcription factor p53 and inhibits its transcriptional activity, resulting in the increased survival of melanoma cells by decreasing p53-dependent apoptosis [61]. When secreted by tumors, S100B can be used as a prognostic biomarker, higher levels of S100B being predictive of poorer outcome [62-64]. S100B also appears to be a promising biomarker for treatment response and overall survival in melanoma patients treated with immune checkpoints inhibitors (anti PD-1 antibodies) [65].

\subsection{Treatment of Cutaneous Melanoma}

Tumor heterogeneity [66] makes the treatment of melanoma tumors very challenging $[67,68]$. In the early stages of the disease, the most effective treatment is surgical resection of the primary tumor, and in these patients, 5-year survival exceeds $95 \%$. However, once it forms metastases, melanoma becomes a very aggressive cancer and without treatment, patients survive less than one year [69].

For many years, patients with metastatic melanoma had very few treatment options. One option was the cytotoxic agent dacarbazine, and two other options were the immunotherapeutic agents interleukin 2 (IL-2) and interferon $\alpha$ (IFN- $\alpha$ ). Treatment with either dacarbazine or IL-2 resulted in low response rates $(<20 \%)$ and transient effects, and it was associated with severe adverse effects. In addition, none of these agents was shown to significantly prolong the overall survival of patients [69]. Some encouraging results with increased overall survivals were observed with interferon a (IFN- $\alpha$ ), but the effects were sub-optimal, and the adverse events were severe for most patients [69]. Significant improvements in metastatic melanoma therapy occurred in the last decade with the approval of new drugs for targeted therapy (BRAF and MEK inhibitors) and immunotherapy (immune check-points inhibitors) (Table 2) [70]. 
Vemurafenib, dabrafenib, and encorafenib inhibit the mutant forms of the BRAF kinase, where valine in position 600 is replaced by an aspartic acid (V600E) or a lysine residue (V600K). These mutations are frequently observed in melanoma tumors, with BRAF V600E mutants being present in up to $60 \%$ of melanoma tumors [71]. Trametinib and binimetinib are MEK inhibitors and used in combination with BRAF mutant inhibitors [72-75]. Although the overall survival of melanoma patients has improved with kinase inhibitors, many patients experienced recurrence of the disease due to different mechanisms of resistance [76]. Three antibodies—ipilimumab, nivolumab, and pembrolizumab—have been approved by the FDA for the treatment of metastatic melanoma (Table 2). These antibodies target two major immunosuppressive checkpoints: the cytotoxic $\mathrm{T}$ lymphocyte antigen 4 protein (CTLA-4) (ipilimumab) and PD-1 (nivolumab and pembrolizumab) [77]. Among these antibodies, nivolumab and pembrolizumab present higher efficacy and safety than ipilimumab [77]. Although these new immunotherapeutic agents result in improved outcomes for patients, compared to other melanoma therapeutic agents, they are also associated with severe adverse effects and are only suitable for the more fit patients [77].

Table 2. Mechanism of action (MOA), overall survival (OS), and date of approval by the Food and Drug Administration (FDA) of selected drugs used for the treatment of metastatic melanoma. The OS data from single drug and recent combination therapies are indicated.

\begin{tabular}{|c|c|c|c|}
\hline Drug & MOA & OS & Approval Year \\
\hline Dacarbazine & Alkylating agent & 9.1 months [78] & 1975 \\
\hline Vemurafenib & BRAF V600E inhibitor & 15.9 months [79] & 2011 \\
\hline $\begin{array}{l}\text { Vemurafenib }+ \\
\text { Cobimetinib }^{1}\end{array}$ & $\begin{array}{l}\text { BRAF V600E inhibitor } \\
\text { MEK inhibitor }\end{array}$ & 22.5 months [80] & 2020 \\
\hline Ipilimumab & CTL-4 blocking antibody & 19.9 months [81] & 2011 \\
\hline Trametinib & MEK inhibitor & 14.2 months [82] & 2013 \\
\hline Dabrafenib & BRAF V600E inhibitor & 13.1 months [82] & 2017 \\
\hline $\begin{array}{l}\text { Dabrafenib + } \\
\text { Trametinib }^{1}\end{array}$ & $\begin{array}{l}\text { BRAF V600E inhibitor } \\
\text { MEK inhibitor }\end{array}$ & 25.9 months [83] & 2019 \\
\hline Nivolumab & PD-1 antibody & 36.9 months [81] & 2015 \\
\hline $\begin{array}{l}\text { Ipilimumab }+ \\
\text { Nivolumab }^{1}\end{array}$ & $\begin{array}{l}\text { CTL-4 blocking antibody } \\
\text { PD-1 antibody }\end{array}$ & 60 months [81] & 2015 \\
\hline $\begin{array}{l}\text { Encorafenib }+ \\
\text { Binimetinib }^{1}\end{array}$ & $\begin{array}{l}\text { BRAF V600E or V600K inhibitor } \\
\text { MEK inhibitor }\end{array}$ & 33.6 months [84] & 2018 \\
\hline Pembrolizumab & PD-1 antibody & 32.7 months [85] & 2019 \\
\hline
\end{tabular}

Despite the important progresses made toward the treatment of metastatic melanoma, the treatment outcomes are still not satisfactory, and it is urgent to continue to improve existing treatments or to develop new therapeutic strategies. As we will discuss in this review, an increasing number of experimental evidences suggests that the receptor for advance glycation end products (RAGE) could be a relevant therapeutic target for the treatment of metastatic melanoma. The next sections of this review will provide information on the role of RAGE in melanoma.

\section{RAGE}

\subsection{RAGE Structure and Isoforms}

RAGE is a single transmembrane domain multi-ligand cell surface receptor belonging to the immunoglobulin (Ig) superfamily and is encoded in the class III Major Histocompatibility Complex (MHC) at position 6p21.3 [86-89]. This chromosomal region contains multiple genes involved in inflammatory and immune disorders, suggesting that RAGE plays a role in inflammation as well [90].

Human RAGE is a multi-domain protein (Figure 1), containing three extracellular domains, a single transmembrane (TM) region, and a short cytoplasmic tail. The variable domain (V), constant domain 1 (C1), and constant domain 2 (C2) constitute the three extracellular domains of RAGE, and they have overall structural folds of variable and constant Ig domains. Full-length RAGE has 404 amino 
acids and contains a 22 amino acid-long signal peptide for targeting to the cell surface. The length of the different domains is as follows: the $\mathrm{V}$ domain comprises amino acids (AAs) 23-116, the C1 domain consists of AAs 124-221, the C2 domain of AAs 227-317, the TM domain of AAs 343-362, and the intracellular domain consists of AAs 363-404 [91-95].

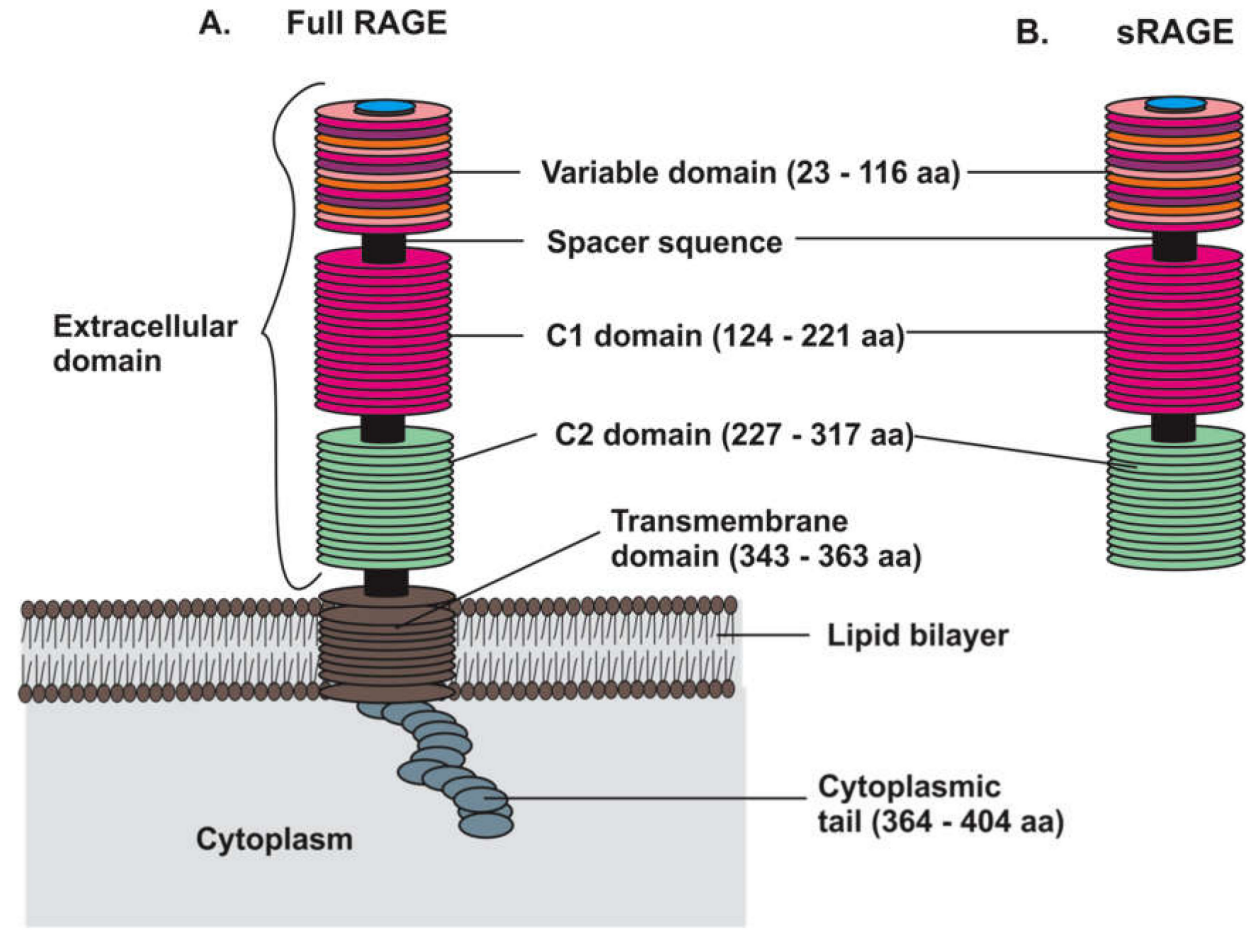

Figure 1. Schematic representation of membrane-bound full-length receptor for advance glycation end products (RAGE) and soluble RAGE (sRAGE). (A) Full-length RAGE consists of three extracellular domains (variable domain (V), constant domain 1 (C1), and constant domain 2 (C2)), a single transmembrane domain, and a short cytoplasmic tail. Short spacer sequences are present between the different domains. (B) sRAGE is formed by the extracellular domains only and lacks the transmembrane domain and the cytoplasmic tail.

The first successful cloning of RAGE was carried out in 1992 from bovine lung [93]. In this study, HEK293 cells transfected with full-length RAGE cDNA showed a main immunoreactive band on a Western blot at $50 \mathrm{kDa}$ and several other bands between 30 and $40 \mathrm{kDa}$, suggesting the presence of post-translational modifications of RAGE [93]. Following this study, other groups confirmed the existence of a soluble isoform of RAGE called soluble (s) RAGE (sRAGE). The sRAGE isoform (Figure 1) lacks the transmembrane region and the C-terminal intracellular region [88]. This soluble isoform can result from cleavage of membrane-bound RAGE by proteolytic enzymes or sheddases such as A Disintegrin and Metalloproteinase 10 (ADAM10) [96,97]. sRAGE can also be a consequence of alternative splicing of pre-mRNA [98]. Although other isoforms of RAGE have been described, full-length RAGE and sRAGE are the most frequently observed isoforms [99-103].

RAGE can form oligomers; however, the physiological or pathological functions of these oligomers is currently unknown. There is evidence that the homodimerization of RAGE is critical to RAGE-mediated signal transduction [104]. In a previous study, we showed that tetrameric S100B could induce RAGE dimerization as a mechanism of RAGE activation [105]. However, other studies suggest that RAGE may be constitutively expressed as oligomers. In fact, Zong et al. demonstrated that the constitutive dimerization of RAGE is essential for ligand recognition [104]. In addition, all three extracellular domains of RAGE present surfaces that enable dimerization $[91,94,106,107]$. For instance, the $\mathrm{V}$ domain contains hydrophobic patches that allow $\mathrm{V}$ domain/ $\mathrm{V}$ domain interaction [108]. In the C1 domain, two $\beta$-strands ( $\mathrm{L}^{133}$ TAGVPNKVGTC ${ }^{144}$ and $\mathrm{F}^{186} \mathrm{TLQSEL}^{192}$ ) can be further stabilized by 
dimerization [109]. In the C2 domain, a proline-rich region assembles into an external loop that may be critical for the formation of oligomers, as suggested in a hexameric model of RAGE [108]. Apart from oligomerization mediated by these domains, a recent study has correlated the oligomerization of the transmembrane domain to the presence of GxxxG motifs of these domains [110]. In general, the formation of dimers and higher order oligomers, such as tetramers and hexamers, are facilitated by electrostatic and hydrophobic interactions between multiple RAGE domain surfaces $[104,108,111]$. Several models of dimeric and higher order oligomeric structures of RAGE have been proposed and are presented in Figure 2.

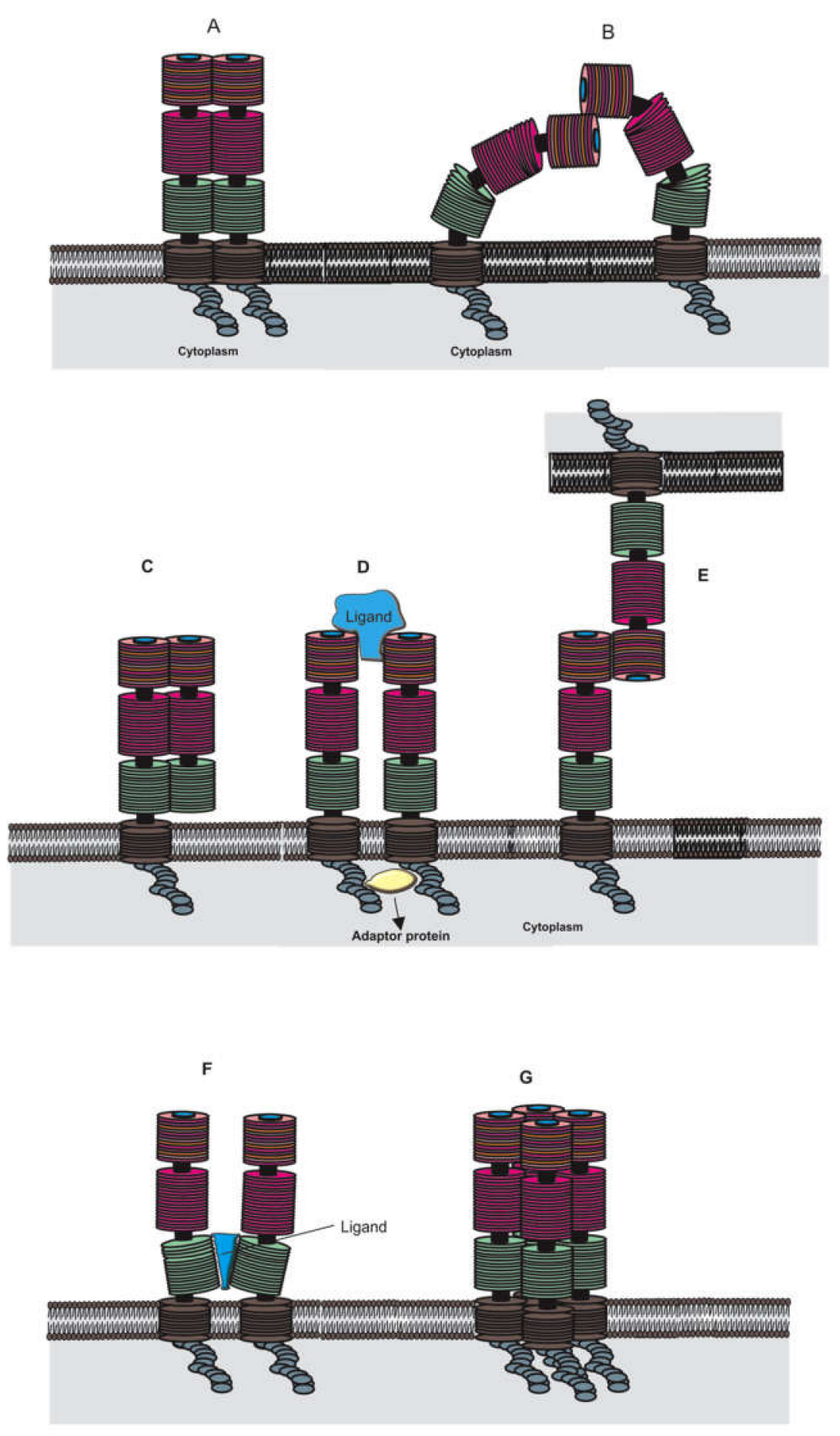

Figure 2. Cont. 


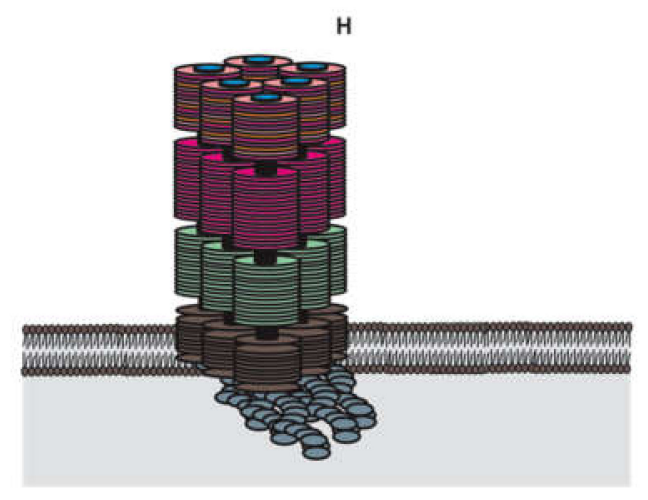

Figure 2. Possible dimeric and oligomeric forms of RAGE. (A) RAGE dimers have been suggested to be required for signal transduction [104]; in this representation, all three extracellular domains and the transmembrane domain are involved in dimer formation. (B) Dimerization via the V domain only [112]. (C) Models for the inhibitory RAGE/sRAGE heterodimer [113]. (D) Ligand-induced RAGE homodimers [105]. (E) Dimerization via the V domain of RAGE between two different cells [114]. (F) Dimerization through a ligand bound to two C2 domains [115]. (G,H) Other oligomeric forms of RAGE have been proposed as well (tetramers and hexamers) [105].

\subsection{RAGE Ligands}

In physiological conditions, RAGE plays a key role in the resolution of inflammation, tissue repair, and bone homeostasis $[116,117]$. However, the high expression and activity of RAGE have been incriminated in disease conditions, such as chronic inflammation [113,118,119], diabetes [120-122], neurodegeneration [123-125], cardiovascular diseases [126-128], and cancers [129-131]. The activity of RAGE is typically mediated by its ligands but can also be caused by receptor up-regulation. RAGE is a pattern recognition receptor that recognizes Damage-Associated Molecular Patterns (DAMPs), thereby culminating to a downstream pro-inflammatory cascade [104]. RAGE ligands include Advanced Glycation End Products (AGE), calgranulins/S100 proteins, $\beta$-amyloid peptides, High Mobility Group Box 1 (HMGB1) protein, transthyretin [132], $\beta 2$ integrin Mac-1 [133], complement proteins C3a and C1q [134-137]. The interaction of RAGE with one or more family of these ligands has been implicated in melanoma and other cancers.

\subsection{S100 Proteins Family}

S100 proteins are small EF-hand calcium binding proteins with diverse intra- and extracellular functions (for reviews, see $[138,139])$. Upon calcium binding, S100 proteins change the conformation and interact with their target proteins that regulate important cellular functions such as cell cycle, cell growth, and migration [138,139]. The role of S100 proteins in cancer is complex, as S100 proteins can have tumor promoter or suppressor effects, depending on the S100 protein and the type of cancer (reviewed in [140,141]). Many members of the S100 protein family are ligands of RAGE [142]. S100 proteins are expressed in many cell types, including melanoma cells. The ability of melanoma cells to secrete S100 proteins was first reported in 1980 [143]. A recent analysis of S100 gene transcripts and clinicopathological data of melanoma patients revealed different expression patterns among different S100 genes, in primary or metastatic melanoma tumors [144]. A first group of genes, including S100A1, S100A13, and S100B was found expressed at high levels in both primary and metastatic melanoma tumors. A second group of S100 genes (S100A2, S100A7, S100A8, S100A9, S100A10, S100A11, and S100P) was highly expressed in primary tumors, but it was expressed at lower levels in metastatic tumors than in control skin [144]. All genes from the second group were strongly correlated with each other, as well as with lymphatic and distant metastases, supporting the role of S100 proteins in melanoma development and suggesting that $\mathrm{S100}$ gene transcript levels could be useful as diagnostic 
markers [144]. The next sections will provide additional information on specific members of the S100 protein family involved in melanoma (Summarized in Table 3).

Table 3. S100 proteins and their roles in melanoma.

\begin{tabular}{|c|c|c|}
\hline S 100 Protein & Roles and Main Target Proteins in Melanoma & References \\
\hline S 100B & $\begin{array}{l}\text { - Higher expression in metastatic than primary } \\
\text { melanoma tumors } \\
\text { - } \quad \text { Used as prognostic marker and indicator of } \\
\text { therapeutic responses } \\
\text { - } \quad \text { Extracellular S100B activates RAGE } \\
\text { - Intracellular S100B prevents p53 activation }\end{array}$ & $\begin{array}{c}{[145]} \\
{[62,65]} \\
{[60,105,113,146]} \\
{[147-149]} \\
\end{array}$ \\
\hline S 100A1 & $\begin{array}{l}\text { - Higher expression in melanoma tumors than benign nevi } \\
\text { - Could modulate melanoma tumor growth through its } \\
\text { interaction with RAGE and TRPM-1 }\end{array}$ & $\begin{array}{l}{[150,151]} \\
{[152-154]}\end{array}$ \\
\hline S 100A2 & $\begin{array}{l}\text { - Lower levels in metastatic than primary tumors } \\
\text { A tumor suppressor role has been suggested, but the } \\
\text { overall role is complex }\end{array}$ & [144,155-157] \\
\hline S 100A4 & $\begin{array}{l}\text { - Stimulates melanoma metastasis through RAGE activation } \\
\text { - Alters endothelial cell integrity }\end{array}$ & {$[158,159]$} \\
\hline S 100A6 & $\begin{array}{l}\text { - Higher expression in metastatic tumors than in benign nevi } \\
\text { - } \quad \text { Up-regulation in RAGE overexpressing tumors } \\
\text { - Interacts with RAGE }\end{array}$ & {$[142,146,156,160,161]$} \\
\hline S 100A8/A9 & $\begin{array}{l}\text { - } \quad \text { Higher levels in metastatic than in primary tumors } \\
\text { - } \quad \text { Potential prognostic marker and predictor of survival } \\
\text { PAGE and S100 Soil Sensor Receptors (SSSRs) }\end{array}$ & [162-164] \\
\hline S 100A13 & $\begin{array}{l}\text { - } \quad \text { Possible role as angiogenic and prognostic marker } \\
\text { - } \quad \text { Facilitates secretion of angiogenic marker FGF } \\
\text { - Participates to dacarbazine resistance }\end{array}$ & {$[144,165-167]$} \\
\hline S $100 P$ & $\begin{array}{l}\text { - Higher levels in metastatic melanoma than in primary } \\
\text { tumors and nevi } \\
\text { Could promote melanoma metastasis through the } \\
\text { interaction with ezrin (intracellular S100P) and RAGE } \\
\text { (extracellular S100P) }\end{array}$ & {$[168,169]$} \\
\hline
\end{tabular}

\subsubsection{S100B}

S100B has been described as the "lineage marker" of malignant melanoma [170]. S100B is the most useful [171] and standard [172] biomarker for the follow-up of melanoma patients. S100B serves as a prognostic factor and predictor of overall survival (OS) in melanoma patients. A recent study showed lower S100B levels from patients with stages I and II (primary melanoma) than stage III (regional melanoma) and stage IV (metastatic melanoma), the levels of S100B being the highest in patients with metastatic melanoma [145]. Apart from its use in clinical staging, S100B protein levels are widely used in the clinical management of melanoma patients to determine therapeutic responses [62]. A recent study showed that S100B levels could be used as a prognostic biomarker in patients treated with immune checkpoints inhibitors [65].

S100B has many different binding targets, including RAGE $[60,105,113]$. We showed that the binding of S100B to RAGE was calcium dependent $[105,113]$, suggesting a link between calcium and RAGE signaling in cells. In a recent study, we also showed that an overexpression of RAGE in the human WM115 melanoma cell line resulted in increased cell migration and invasion [173]. When injected into mice, we showed that the RAGE overexpressing melanoma tumors expressed higher levels 
of S100B than WM115 control tumors [146], suggesting a positive correlation between RAGE, S100B, and melanoma malignancy. Our data also demonstrated that the RAGE/S100B axis was involved in melanoma development and growth. In addition to its extracellular function, S100B has important intracellular roles. One of these intracellular functions is the regulation of the tumor suppressor p53 protein. The regulation of p53 activity by S100B is complex, and three mechanisms of regulation have been found. S100B can directly reduce p53 activity by binding to the C-terminal oligomerization domain of p53 [147], thereby preventing p53 oligomerization and activation. In vitro data also showed that $\mathrm{S} 100 \mathrm{~B}$ can inhibit the phosphorylation and regulation of p53 by protein kinase C [148]. In addition, S100B was shown to reduce the tumor-suppressive activities of $\mathrm{p} 53$ by down-regulating the expression of p53 downstream effector genes [149].

\subsubsection{S100A1}

S100A1 is also highly expressed in melanoma tumors, but it differs from S100B in that it is not actively secreted in the serum. Semiquantitative scoring analysis of S100A1 in paraffin-embedded sections of 18 conjunctival nevi, 16 conjunctival melanomas, and 20 uveal melanomas found that S100A1 was more frequently expressed in conjunctival melanoma ( $71.4 \%$ positive cells) and uveal melanoma $(88.5 \%)$ than in conjunctival nevi (30.6\%) [150]. In a different study, the immunohistochemical analysis of melanoma tissues showed a comparatively higher expression of S100A1 in melanoma than in benign melanocytic tumors [151], suggesting that S100A1 may play a critical role in melanoma progression. At the cellular level, S100A1 has been shown to interact with the transient receptor potential melastatin-1 (TRPM-1) channel [153]. TRPM-1 is an important mediator of calcium influx in cells and has been described as a tumor suppressor in melanoma [174]. S100A1 interaction with TRPM-1 could therefore be an important component in melanoma progression. We showed that S100A1 interacts with RAGE in the presence of calcium [152]. A recent study also suggested that S100A1 competes with S100A4 for binding to the V-domain of RAGE [154], suggesting that S100A1/RAGE interaction might influence cell proliferation in melanoma.

\subsubsection{S100A2}

Earlier studies suggested that S100A2 plays the role of tumor suppressor in melanoma [156,157]. When using a xenograft mouse model, we showed that the overexpression of RAGE in WM115 human melanoma cells implanted in mice resulted in about 1.5 fold higher expression of S100A2 in tumor tissues, as compared to control tumors [146]. However, an analysis of S100 gene transcripts in melanoma tumor samples from different stages showed that the levels of S100A2 transcripts were lower in metastatic melanoma tumors than primary tumors [144]. We had also observed lower levels of S100A2 transcripts in stage III and IV melanoma samples than in control skin samples [155]. These data suggest a complex role of S100A2 in melanoma progression that needs to be further investigated.

\subsubsection{S100A4}

In many cancers, S100A4 has been shown to stimulate tumor proliferation and metastasis $[175,176]$. S100A4 is a ligand of RAGE $[141,152]$ and has been shown to stimulate metastasis in various cancer models, including melanoma, through its interaction with RAGE $[158,159,177]$. Herwig et al. recently showed that the A375 human metastatic melanoma cell line actively secreted S100A4, which acted as an autocrine and paracrine stimulator of RAGE expression [159]. In the same study, the authors reported that the interaction of S100A4 with RAGE resulted in prometastatic activation of A375 cells, with decreased cellular adhesion to fibronectin, increased cell motility, invasiveness, and tumor growth [159]. In a follow-up study, these authors showed that the S100A4/RAGE signaling altered endothelial cell integrity by decreasing tight junction proteins (occludin) and adherence junction protein (E-cadherin) [178]. The authors further showed that S100A4 or RAGE overexpressing A375 cells transmigrated to a higher extent through endothelial cells than control non-transfected A375 cells [178]. All these in vitro data were supported by studies using a mouse model of metastatic melanoma, where 
mice injected with S100A4 or RAGE overexpressing A375 cells showed higher tumor incidence and mortality than mice injected with the control non-transfected A375 [178]. Additionally, we previously demonstrated that S100A4 levels were significantly higher in RAGE overexpressing WM115 tumors, which were subcutaneously implanted in mice, than in control tumors generated from non-transfected WM115 cells [173]. The results of these studies strongly suggest that the S100A4/RAGE axis is an important contributor to metastasis in melanoma tumors.

\subsubsection{S100A6}

The expression of S100A6 was described in cutaneous and extracutaneous lesion including melanocytic nevi and malignant melanoma [179]. S100A6 is overexpressed in Spitz nevi, melanocytic nevi, and melanomas [160]; in fact, tissue analysis of melanoma patients revealed that most melanomas showed positive staining for S100A6 [161]. Interestingly, many studies have suggested a role of S100A6 in metastasis, although the exact metastatic mechanism is not specified. An early study revealed a positive correlation between the overexpression of S100A6 and the metastasis of human melanoma cell lines [180]. In another study, gene expression analysis in 45 metastatic melanoma and 20 benign nevi indicated significantly higher levels of S100A6 in metastatic melanoma than in benign nevi [156]. In our xenograft mouse model of melanoma, S100A6 was also found up-regulated in tumors from RAGE overexpressing WM115 melanoma cells compared to tumors from control WM115 cells [146]. Therefore, S100A6 up-regulation may be an important driver in melanomagenesis. In addition, the expression and staining pattern of S100A6 might be useful in distinguishing different forms of melanoma [181].

\subsubsection{S100A8/A9}

The heterodimeric S100A8/A9 is a complex of two S100 proteins, S100A8 and S100A9. Although S100A8 and S100A9 homodimers have been described [182], the heterodimeric form of these proteins is more frequently observed [139]. Extracellular S100A8/A9 can bind to RAGE and other receptors, thus contributing significantly to the progression of melanoma. In a mouse model of metastatic melanoma, it was shown that uteroglobulin knock-out mice, which naturally overexpress S100A8/A9 in their lungs, developed more metastases in this organ than their wild-type littermates [162]. This study suggested that S100A8/A9 had the ability to attract melanoma cells to the lungs through the activation of RAGE. In a more recent study, the role of S100A8/A9 as a lung attractant for melanoma metastases was confirmed [163]. In this study, the authors showed that a neutralizing antibody against S100A8/A9 could reduce the formation of melanoma metastases in the lungs of mice [163]. S100A8/A9 has also been proposed to be a prognostic marker for metastasis, as well as a predictor of survival and determinant of therapeutic response in melanoma patients [164]. When the expressions of S100A8/A9 proteins were analyzed in melanocytic nevi, primary melanomas, and metastases, higher expression was found in metastases compared to primary melanoma tumors, suggesting that S100A8/A9 is a tumor microenvironment-associated protein that is key to the process of metastasis in melanoma [164].

Other than RAGE, S100A8/A9 recognizes and binds to an array of receptors described as S100 Soil Sensor Receptors (SSSRs) [183]. SSSRs encompass Extracellular Matrix Metalloproteinase Inducer (EMMPRIN), Activated Leukocyte Cell Adhesion Molecule (ALCAM), Toll-like Receptor 4 (TLR-4), Neuroplastin (NPTN) $\beta$, and Melanoma Cells Adhesion Molecule (MCAM) [183-185]. S100A8/A9/RAGE, S100A8/A9-ALCAM, and S100A8/A9/MCAM axes mediate malignant melanoma progression through the activity of nuclear factor kappa beta (NF- $\mathrm{KB}$ ) and production of reactive oxygen species (ROS) [185]. Recently, Chen et al. [186] reported the underlining mechanism of melanoma lung tropic metastasis mediated by the S100A8/A9/MCAM axis. This involves the processional activation of MAPKKK8 (Tumor progression locus 2 (TPL2)), ETS translocation variant 4 (ETV4), and induction of matrix metalloproteinase 25 (MMP-25) [186]. 


\subsubsection{S100A13}

An expression analysis of S100 genes in melanoma tissues revealed that S100A13 was found highly expressed in melanoma samples [144], although little is known about the contribution of S100A13 to the progression of melanoma. Massi et al. suggested that S100A13 could serve as an angiogenic and prognostic marker in melanoma [165]. Rapidly dividing cancer cells require a high amount of nutrients and oxygen. In order to meet these demands, angiogenesis provides tumor vascularization. The entire process depends on the expression of specific factors such as the Vascular Endothelial Growth Factor (VEGF), and Fibroblast Growth Factors (FGFs). Previous studies have demonstrated a role of S100A13 in the secretion of the FGF, thereby facilitating angiogenesis [166]. In another study, S100A13 was identified as a key player in the resistance of Cutaneous Malignant Melanoma (CMM) to dacarbazine therapy [167], suggesting multiple roles of S100A13 in melanoma metastasis and drug resistance.

\subsubsection{S100P}

$\mathrm{S} 100 \mathrm{P}$ is another protein of the S100 family. It was designated "P" because it was first purified from placenta [187]. Higher levels of S100P were reported in primary melanoma than in nevi and in metastatic melanoma than in primary tumors [168]. A positive correlation was also reported between the expression levels of RAGE and S100P in melanoma tumors [169]. S100P can be localized inside cells or be secreted in the extracellular space; both intracellular and extracellular S100P have been incriminated in tumor proliferation and metastasis [169]. Although RAGE appears to be the receptor for extracellular S100P, the cytoskeletal protein ezrin was found to interact with S100P in the intracellular compartment [169]. Ezrin plays a critical role in cell-cell and cell-matrix contacts. Accumulating evidences suggest that the binding of S100P to ezrin could initiate cell migration in malignant melanoma $[188,189]$.

\subsection{HMGB1}

High Mobility Group Box-1 (HMGB1) was previously referred to as the "chromatin-associated protein" because of its nuclear localization and its activities of modulator transcription and DNA recombination [190-193]. It is now well established that HMGB1 has also important extracellular functions [194-197]. Structurally, HMGB1 encompasses three domains, with two identical DNA-binding regions called box A and box B, and a negatively charged C-terminus tail [195]. The major contribution of extracellular HMGB1 to invasiveness and tumor metastasis occurs via its interaction with RAGE [198-200]; however, an intracellular role of HMGB1 in tumor progression has also been reported [201].

In tumors, HMGB1 can be released into the extracellular space during necrosis [202] as well as under hypoxic conditions [203]. Extracellular HMGB1 has been shown to interact with RAGE and other cell surface receptors $[196,204]$. Activation of the HMGB1/RAGE signaling can lead to cell proliferation [205], inflammatory responses [206,207], cell migration [208], chemotaxis, and cytoskeleton reorganization [209].

In melanoma, Tang et al. reported that disruption of the HMGB1/RAGE axis hampered melanoma tumor growth and reduced the synthesis of inflammatory cytokines [210]. This showed that the interaction of HMGB1 with RAGE was critical to maintain an inflamed tumor microenvironment and to tumor growth [210]. The HMGB1/RAGE axis has also been shown to be critical for melanomagenesis. Zhang et al. reported that repeated UV radiation exposure of human melanocytes resulted in an increased secretion of HMGB1 and resistance to subsequent UV-induced apoptosis [211]. Importantly, silencing RAGE in these melanocytes resulted in a decreased secretion of HMGB1 as well as decreased resistance to apoptosis, strongly suggesting that the HMGB1/RAGE axis contributes to the early stages of melanoma development [211]. In a different study, Wang et al. reported that in melanocytes, UV exposure resulted in an increased expression of PD1L1 through the activation of the HMGB1/RAGE axis, and it resulted in significant reduction of the susceptibility of melanoma cells to CD8+ T-cell-dependent cytotoxicity, further demonstrating the important role of the HMGB1/RAGE axis in melanoma 
development [212]. A recent study also reported that HMGB1 expression levels were higher in patients who did not respond to the immune checkpoint inhibitor ipilimumab than in responding patients, supporting a role of the HMGB1/RAGE axis in enabling a tumor-promoting microenvironment [213].

\subsection{Advanced Glycation End Products}

Advanced Glycation End Products (AGEs) are substances that are formed as a result of non-enzymatic browning or glycation [214]. AGEs are usually formed when reducing sugars react with the amino moiety of proteins in a multi-step reaction involving the generation of intermediates molecules, such as Schiff bases and Amadori products. The overall reaction is called the Maillard reaction [215-218].

Several studies have demonstrated a role of the AGE/RAGE axis in melanoma progression. In vitro, RAGE was found expressed at higher levels in melanoma cells than melanocytes [219]. In two different studies, AGEs were shown to increase melanoma cell proliferation and migration, tumor growth, and metastasis, in a RAGE-dependent manner $[219,220]$. Recently, Nakamura et al. showed that melanoma growth and the formation of liver metastases could be reduced when using RAGE-targeting DNA aptamers [221]. The decrease in melanoma growth was associated with a decrease in expression levels of RAGE [221]. In the same study, the authors showed that the exposure of human G361 melanoma cells to AGEs in vitro resulted in increased ROS generation and cell proliferation, as well as increased expression of cyclin D1 and p27, vascular endothelial growth factor (VEGF), and the monocyte chemoattractant protein 1 (MCP-1) [221]. In a similar study, Ojima et al. showed that DNA aptamers could also prevent tumor growth by inhibiting angiogenesis via the disruption of the AGE/RAGE axis [222]. Overall, it was found that the AGE/RAGE axis was critical to melanoma tumor growth and angiogenesis formation.

\subsection{RAGE Signaling Pathways}

RAGE signaling has been incriminated in many diseases including cancer, complications of diabetes, and neurodegenerative disorders [137,223-227]. However, RAGE signaling is also important in many physiological processes such as tissue repair and bone homeostasis $[116,228]$. Typically, RAGE signaling depends on the type of ligand, its concentration, as well as the cell type, making RAGE a complex receptor to target therapeutically (reviewed in [229]). RAGE signaling is initiated by the interaction of the ligand with the extracellular part of the receptor, mostly the V-domain. Apart from the extracellular domain of RAGE, the short cytoplasmic domain of RAGE is also key in RAGE signaling. Many studies have shown that the deletion of this segment resulted in an inhibition of RAGE signaling, and dominant negative effects were reported as well [230-232]. Several adaptor proteins interacting with the cytoplasmic domain of RAGE have been identified. Hudson et al. reported that the FH1 domain of Diaphanous-1 (Dia-1) was essential for the transmission of RAGE signals through the activation of the small GTPases Rac1 and cell division control protein 42 (Cdc42), resulting in cell migration (Figure 3) [233]. Apart from Dia-1, other adaptor proteins transducing RAGE signaling have been identified: Toll-Like Receptor $2 / 4$ adaptors (TIRAP) and myeloid differentiation primary response 88 (MyD88) have also been shown to interact with the RAGE intracellular domain and to mediate RAGE-dependent signal transduction (Figure 3) [234]. 


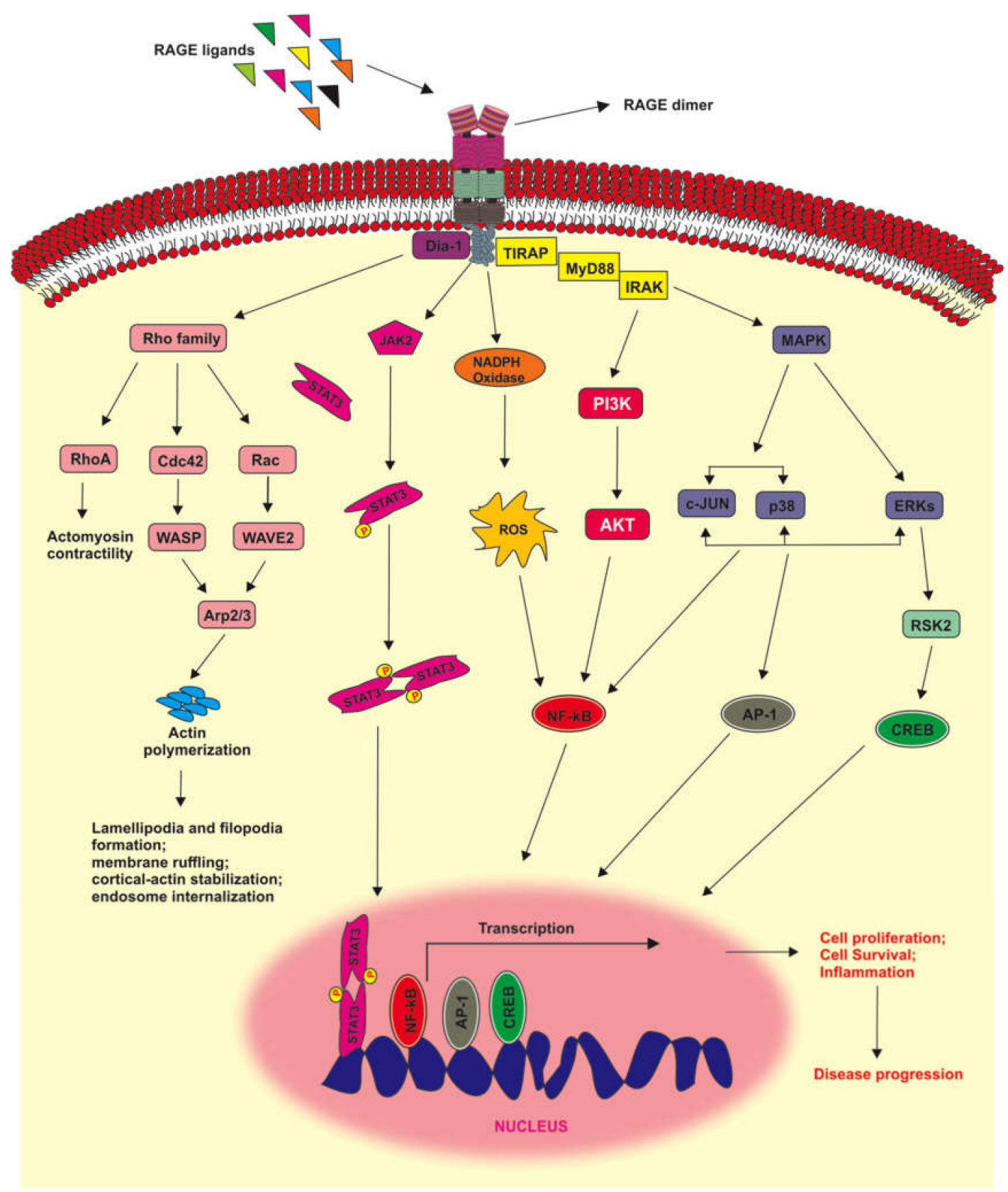

Figure 3. RAGE signaling pathways. The C-terminus cytoplasmic tail of RAGE is crucial to RAGE signaling. Two adaptor proteins interacting with the cytoplasmic tail of RAGE have been identified: Dia-1 and TIRAP [233,234]. RAGE activation leads to increased cell migration through the activation of several members of the Rho family of small GTPases, including RhoA, Cdc42, and Rac-1 [230,233]. The signaling cascades of these proteins (Dia-1/RhoA; Dia-1/Cdc42/Wiskott-Aldrich syndrome protein (WASP)/actin related protein (Arp); Dia-1/Rac/WASP family verprolin-homologous protein-2 (WAVE2)/Arp) lead to actomyosin contractility and actin polymerization [235]. Similarly, RAGE-mediated activation of Janus kinase (JAK) leads to the downstream phosphorylation of Signal transducer and activator of transcription (STAT) 3 and its subsequent dimerization resulting in gene transcription $[236,237]$. Additionally, nicotinamide adenine dinucleotide phosphate (NADPH) oxidase can be activated, leading to ROS generation, which leads to NF- $\mathrm{BB}$ activation [238]. RAGE/PI3K/AKT, RAGE/MAPK/c-JUN, RAGE/MAPK/p38, and RAGE/MAPK/Extracellular signal-related kinase (ERK) axes can also result in the activation of NF-KB [239-241]. In addition to NF- $\mathrm{BB}$, RAGE has also been shown to signal through AP-1 and cyclic AMP response element-binding protein (CREB) [242-244]. 
Rac- 1 and cdc42 proteins belong to the Rho family of small GTPases that are involved in membrane ruffles-initiated cell migration via lamellipodia and filopodia formation [245]. Accumulating evidence suggests that Rac-dependent motility occur via the WASP-family verprolin-homologous protein-2 (WAVE2)/actin-related protein 2/3 (Arp2/3) signaling pathway $[235,246]$. Another member of the Rho family, RhoA, together with Cdc42, has also been shown to initiate metastasis as a result of the activation of RAGE by S100A4 [247]. The activation of RhoA is critical to cell migration and motility through the phosphorylation of myosin-II light chain and actomyosin contractility (Figure 3) [248-250].

One important downstream signaling pathway activated by RAGE is the MAP kinase pathway $[239,251]$. The MAPK system includes ERK1/2, c-Jun N-terminal Kinases (JNKs, JNK/SAPK), and p38 MAPK (Figure 3) [252]. Activation of this pathway usually results in the activation of NF-KB [251]. Other signaling pathways activated by RAGE have been described: the RAGE/NADPH/ROS [253] and RAGE/PI3K/AKT pathways [254], also leading to the activation of NF-kB (Figure 3) [251]. Most recently, RAGE has also been shown to promote inflammation through the activation of the thioredoxin interacting protein (TXNIP), linking the RAGE/TXNIP axis with the activation of NLR family pyrin domain containing 3 (NLRP3) inflammasone activation (Figure 3) [255,256].

$N F-K B$ is a dimeric transcription factor that belongs to the Rel1 gene family of DNA-binding proteins, and it regulates the transcription of cytokines, growth factors, and anti-apoptotic proteins, thus playing vital roles in proliferation, angiogenesis, metastasis, survival, and immune responses [257]. Another downstream target of RAGE is the Janus kinase 1/2 (JAK1/2)/Signal transducer and activator of transcription (STAT) cascade. Studies have shown that the JAK2-STAT1/STAT3 mediated production of collagen in NRK-49F cells was dependent on the AGE/RAGE axis [236]. In a different study, activation of the AGE-RAGE axis resulted in the upregulation of the immunoproteasome via the JAK2/STAT1 pathway, further confirming the diversity of cellular processes controlled by RAGE and its ligands (Figure 3) [258].

In addition to NF- $\mathrm{KB}$ and STATs, other transcription factors are modulated by RAGE activation. Studies have shown that the cyclic AMP response element-binding protein (CREB) can be activated via the RAGE/ERK/RSK2 dependent cascade, resulting in the nuclear translocation of CREB and resultant expression of chromogranin [243]. In another study, inhibition of the HMGB1/RAGE axis suppressed the ERK/p90 ribosomal S6 kinase (p90RSK)/CREB signaling pathway, resulting in the apoptosis in HGC-27 cells [244]. RAGE activation can also lead to the activation of the transcription factor AP-1 though the stimulation of cdc42/Rac-1/JNK [242] or PI3K/Akt/c-Jun [259]. Activation of the RAGEthioredoxin interacting protein (TXNIP) axis has also been described recently (Figure 3) $[255,256]$.

The influence of RAGE localization on its signaling has been investigated by Popa et al. [260]. In the human primary melanoma cell lines MelJuSo and A375, RAGE was found to have a polarized distribution where RAGE was localized intracellularly and in patches found mostly at membrane ruffles or at other times in cell-to-cell contact sites [260]. However, RAGE localization was more dispersed, with some accumulation at cell profusions, in the metastatic cell lines SK-Me128 and MNT-1 [260]. These authors also identified differences in oligomeric forms of RAGE between the primary and metastatic melanoma cell lines, suggesting that both cellular localization and receptor oligomerization could be important modulators for RAGE signaling [260].

\section{RAGE Signaling in Melanoma Tumors}

An increasing amount of evidence generated from in vitro and in vivo studies suggests that RAGE signaling is an important contributor to the proliferative, inflammatory, and invasive phenotypes of melanoma tumors (reviewed in [261]). Studies have shown that RAGE signaling from both melanoma cells and non-melanoma cells (fibroblasts, immune cells, endothelial cells) present in the tumor microenvironment is an important contributor to melanoma tumor growth.

In tumors, endothelial cells from newly formed blood vessels play major roles by supplying tumor cells with the needed oxygen and nutrients [262]. RAGE is expressed in endothelial cells and in an inflammatory disease model; RAGE activation by its S100B ligand has been shown to increase the 
expression of the adhesion molecules vascular cell adhesion molecule 1 (VCAM-1) and intercellular adhesion molecule 1 ICAM-1, thereby facilitating the adhesion and recruitment of leukocytes to the site of inflammation [95]. In our earlier study, we observed that RAGE overexpressing WM115 melanoma cells also overexpressed S100B, when compared to control WM115 cells [146]. When secreted into the tumor milieu, S100B produced by melanoma cells could act in a paracrine manner on the nearby endothelial cells, resulting in activation of the S100B/RAGE axis, activation of NF-kB, and the recruitment of immune cells to the tumors, sustaining an inflammatory microenvironment [95]. HMGB1 secreted by melanoma tumors has also been shown to activate endothelial cells through the engagement of RAGE, also resulting in the expression of the adhesion molecules VCAM-1, ICAM-1, and E-selectin, and in the recruitment of immune cells in the tumors, as well as in the secretion of the pro-inflammatory cytokines IL-8 and G-CSF to sustain an inflammatory tumor milieu $[263,264]$.

Macrophages present in the tumor microenvironment also contribute to sustaining inflammation [265]. In macrophages, the engagement of RAGE by its ligands, such as HMGB1, has been shown to activate NADPH oxidase, leading to the generation of reactive oxygen species (ROS) and the downstream activation of NF- $\mathrm{kB}$, the expression of pro-inflammatory cytokines (Il-1, IL-6 and tumor necrosis factor alpha (TNF- $\alpha$ ), synthesis of nitric oxide (NO) and superoxide, and resulting in pro-tumoral activities [253,266-268]. RAGE signaling in cytotoxic T cells also contribute to fueling inflammation in the tumor microenvironment. Indeed, the HMGB1/RAGE axis was found to influence melanoma tumor growth through the expression of IL-23 and IL-17 from a sub-population of T cells, (gdT cells), resulting in the activation of STAT-3 in a IL-6 dependent manner [210].

In addition to contributing to inflammation in tumors, RAGE signaling promotes immunosuppression in melanoma tumors. A recent study showed that the HMGB1/RAGE axis played a key role in the suppression of cytotoxic $\mathrm{T}$ cells activity by increasing the expression levels of PD1L1, leading to PD-1 receptor activation and the down-regulation of cytotoxic T-cells [53,212]. Wild et al. also showed that HMGB1 enhanced the inhibitory functions of Tregs through the activation of RAGE, resulting in an immunosuppressive milieu [269]. Recent studies have established a link between chronic inflammation and immunosuppression in tumors [270], and signaling from the RAGE/ligand axis appears to further support this association. Therefore, the data presented in this review suggest that targeting RAGE in melanoma tumors could have benefits for patients.

\section{Conclusions}

A mounting number of experimental findings and observations has shown that RAGE plays a key role in the progression of melanoma through multiple axes. First, RAGE activation in melanoma cells results in increased cell proliferation and cell migration. As RAGE activation by its ligands results in higher expression of the RAGE receptor itself and of its ligands, RAGE activation can lead to sustained tumor growth. In the tumor stroma, mounting evidence supports the notion that the activation of RAGE expressed on multiple cell types, including endothelial cells, macrophages, and T cells, promotes an inflammatory milieu and sustained inflammation, thereby promoting tumor growth. However, RAGE signaling also controls the immunosuppressive activities of Treg, further facilitating tumor growth and metastasis. Taken together, it appears that targeting RAGE in melanoma tumors with high RAGE expression could be a valid approach to improve current chemo- and immunotherapeutic treatments.

Author Contributions: Conceptualization, E.L., Resources, E.L., writing-original draft preparation, O.T.O. and S.K.; writing — review and editing, E.L. and S.W.V.; supervision, E.L.; project administration, E.L.; funding acquisition, E.L. All authors have read and agreed to the published version of the manuscript.

Funding: This work was supported in part by the College of Health Professions at NDSU and by the NIH Grant U54 GM128729 from the National Institute of General Medicine (NIGMS). This work was also supported by a scholarship to S.K. from Jazan University (Saudi Arabia). The data that support the findings of this study are available on request from the corresponding author.

Conflicts of Interest: The authors declare no conflict of interest. 
Abbreviations

\begin{tabular}{|c|c|}
\hline RAGE & Receptor for advanced glycation end product \\
\hline HMGB1 & High Mobility Group Box 1 \\
\hline MSH & Melanocyte stimulating hormone \\
\hline MC1-R & Melanocortin 1 receptor \\
\hline CDKN2A & Cyclin-dependent kinase inhibitor 2A \\
\hline MAPK & Mitogen-activated protein kinase \\
\hline NRAS & Neuroblastoma RAS viral oncogene homolog \\
\hline BRAF & V-raf murine sarcoma viral oncogene homolog B1 \\
\hline PI3K & Phosphatidylinositol-3 kinase \\
\hline mTOR & Mammalian target of rapamycin \\
\hline NF1 & Neurofibromatosis type1 \\
\hline ARID2 & AT-rich interactive domain-containing protein 2 \\
\hline TP53 & Tumor protein p53 \\
\hline PPP6C & Serine/threonine-protein phosphatase 6 catalytic subunit \\
\hline DDX3X & DEAD-box helicase 3 X-linked \\
\hline PTEN & Phosphatase and tension homology \\
\hline RAC1 & ras-related C 3 botulinum toxin substrate 1 \\
\hline FBXW7 & F-box/WD repeat-containing protein 7 \\
\hline SNX31 & sorting nexin 31 \\
\hline PREX2 & phosphatidylinositol-3,4,5- trisphosphate-dependent rac exchange factor 2 \\
\hline TACC1 & transforming acidic coiled-coil-containing protein 1 \\
\hline KIT & KIT tyrosine-protein kinase \\
\hline IDH1 & isocitrate dehydrogenase1 \\
\hline RB1 & retinoblastoma protein 1 \\
\hline SF3B1 & splicing factor $3 \mathrm{~b}$ subunit 1 \\
\hline CTNNB1 & catenin (cadherin-associate protein) beta 1 \\
\hline PIK3CA & phosphatidylinositol-4,5-bisphosphate 3-kinase catalytic subunit alpha \\
\hline CDK4 & cyclin-dependent kinase 4 \\
\hline RASA2 & ras p21 protein activator 2 \\
\hline WT1 & Wilms' tumor suppressor gene 1 \\
\hline EZH2 & enhancer of zeste homolog 2 \\
\hline STK19 & serine/threonine-protein kinase 19 \\
\hline SSM & superficial spreading melanoma \\
\hline AJCC & American joint commission in cancer \\
\hline OS & Overall survival \\
\hline DSS & Disease-specific survival \\
\hline LDH & Lactate dehydrogenase \\
\hline PD1L1 & Programmed cell death receptor 1 ligand 1 \\
\hline PD-1 & Programmed cell death receptor 1 \\
\hline IL-2 & Interleukin 2 \\
\hline IFN- $\alpha$ & Interferon alpha \\
\hline FDA & Food and drug administration \\
\hline CTLA-4 & Cytotoxic T lymphocyte antigen 4 \\
\hline MHC & Major histocompatibility complex \\
\hline $\mathrm{TM}$ & Transmembrane \\
\hline V & Variable \\
\hline $\mathrm{C} 1$ & Constant domain 1 \\
\hline $\mathrm{C} 2$ & Constant domain 2 \\
\hline DAMPS & Damage-associated molecular patterns \\
\hline AGE & Advanced glycation end products \\
\hline TRPM-1 & Transient receptor potential melastatin-1 \\
\hline SSSRs & S100 soil sensor receptor \\
\hline
\end{tabular}




$\begin{array}{ll}\text { EMMPRIN } & \text { Extracellular matrix metalloproteinase inducer } \\ \text { ALCAM } & \text { Activated leukocyte cell adhesion molecule } \\ \text { TLR-4 } & \text { Toll-like receptor } 4 \\ \text { NPTN } \beta & \text { Neuroplastin } \beta \\ \text { MCAM } & \text { Melanoma cells adhesion molecule } \\ \text { NF-kB } & \text { Nuclear factor kappa beta } \\ \text { ROS } & \text { Reactive oxygen species } \\ \text { TPL2 } & \text { Tumor progression locus } 2 \\ \text { ETV4 } & \text { ETS translocation variant } 4 \\ \text { MMP-25 } & \text { Matrix metalloproteinase } 25 \\ \text { VEGF } & \text { Vascular endothelial growth factor } \\ \text { FGF } & \text { Fibroblast growth factor } \\ \text { CMM } & \text { Cutaneous malignant melanoma } \\ \text { MCP-1 } & \text { Monocyte chemoattractant protein } 1 \\ \text { Dia-1 } & \text { Diaphanous-1 } \\ \text { cdc } 42 & \text { Cell division control protein } 42 \\ \text { TIRAP } & \text { Toll-like receptor } 2 / 4 \text { adaptors } \\ \text { MyD88 } & \text { Myeloid differentiation primary response } 88 \\ \text { ERK } & \text { Extracellular signal-related kinase } \\ \text { JNK } & \text { C-Jun N-terminal kinase } \\ \text { TXNIP } & \text { Thioredoxin interacting protein } \\ \text { NLRP3 } & \text { NLR family pyrin domain containing 3 } \\ \text { JAK } & \text { Janus kinase } \\ \text { STAT } & \text { Signal transducer and activator of transcription } \\ \text { CREB } & \text { Cyclin AMP response element-binding protein } \\ \text { RSK2 } & \text { Ribosomal S6 kinase 2 } \\ \text { VCAM-1 } & \text { Vascular cell adhesion molecule 1 } \\ \text { ICAM-1 } & \text { Intercellular adhesion molecule 1 } \\ \text { TNF- } \alpha & \text { Numor necrosis factor alpha } \\ \text { NO } & \text { Regulatory T cells } \\ \text { Tregs } & \end{array}$

\section{References}

1. Shain, A.H.; Bastian, B.C. From melanocytes to melanomas. Nat. Rev. Cancer 2016, 16, 345-358. [CrossRef] [PubMed]

2. Howlader, N.; Noone, A.M.; Krapcho, M.; Miller, D.; Brest, A.; Yu, M.; Ruhl, J.; Tatalovich, Z.; Mariotto, A.; Lewis, D.R.; et al. SEER Cancer Statistics Review, 1975-2017; National Cancer Institute: Rockville, MD, USA, 2020.

3. Bertolotto, C. Melanoma: From Melanocyte to Genetic Alterations and Clinical Options. Scientifica 2013, 2013, 1-22. [CrossRef] [PubMed]

4. Nordlund, J.J. The Melanocyte and the Epidermal Melanin Unit: An Expanded Concept. Dermatol. Clin. 2007, 25, 271-281. [CrossRef]

5. Riley, P. Melanin. Int. J. Biochem. Cell Biol. 1997, 29, 1235-1239. [CrossRef]

6. Breathnach, A.S. Extra-Cutaneous Melanin. Pigment. Cell Res. 1988, 1, 234-237. [CrossRef] [PubMed]

7. Palmieri, G.; Italian Melanoma Intergroup for the Italian Melanoma Intergroup (IMI); Colombino, M.; Casula, M.; Manca, A.; Mandalà, M.; Cossu, A. Molecular Pathways in Melanomagenesis: What We Learned from Next-Generation Sequencing Approaches. Curr. Oncol. Rep. 2018, 20, 1-16. [CrossRef] [PubMed]

8. Palmieri, G.; Eombra, M.; Ecolombino, M.; Ecasula, M.; Esini, M.; Emanca, A.; Epaliogiannis, P.; Eascierto, P.A.; Ecossu, A. Multiple Molecular Pathways in Melanomagenesis: Characterization of Therapeutic Targets. Front. Oncol. 2015, 5, 183. [CrossRef]

9. Bertrand, J.; Steingrimsson, E.; Jouenne, F.; Paillerets, B.; LaRue, L. Melanoma Risk and Melanocyte Biology. Acta Derm. Venereol. 2020, 100, adv00139. [CrossRef] 
10. Curioni-Fontecedro, A.; Pitocco, R.; Schoenewolf, N.L.; Holzmann, D.; Soldini, D.; Dummer, R.; Calvieri, S.; Moch, H.; Fitsche, A.; Mihic-Probst, D. Erratum to "intratumoral heterogeneity of MAGE-C1/CT7 and MAGE-C2/CT10 expression in mucosal melanoma". BioMed Res. Int. 2019, 2019, 5256364. [CrossRef]

11. Iga, N.; Otsuka, A.; Hirata, M.; Kataoka, T.; Irie, H.; Nakashima, C.; Matsushita, S.; Uchi, H.; Yamamoto, Y.; Funakoshi, T.; et al. Variable indoleamine 2,3-dioxygenase expression in acral/mucosal melanoma and its possible link to immunotherapy. Cancer Sci. 2019, 110, 3434-3441. [CrossRef]

12. Petrella, T.M.; Fletcher, G.G.; Knight, G.; McWhirter, E.; Rajagopal, S.; Song, X.; Baetz, T.D. Systemic adjuvant therapy for adult patients at high risk for recurrent cutaneous or mucosal melanoma: An Ontario Health (Cancer Care Ontario) clinical practice guideline. Curr. Oncol. 2020, 27, e43-e52. [CrossRef] [PubMed]

13. Donizy, P.; Wu, C.-L.; Mull, J.; Fujimoto, M.; Chłopik, A.; Peng, Y.; Shalin, S.C.; Selim, M.A.; Puig, S.; Fernández-Figueras, M.T.; et al. Up-Regulation of PARP1 Expression Significantly Correlated with Poor Survival in Mucosal Melanomas. Cells 2020, 9, 1135. [CrossRef] [PubMed]

14. Fujimura, T.; Kambayashi, Y.; Ohuchi, K.; Amagai, R.; Sato, Y.; Tanita, K.; Hashimoto, A.; Aiba, S. Successful Treatment of a Patient with anti-PD1 Antibody-Resistant Advanced Mucosal Melanoma with Nivolumab, Ipilimumab plus Denosumab Combination Therapy. Case Rep. Oncol. 2020, 13, 271-275. [CrossRef] [PubMed]

15. Nishiya, A.T.; Nagamine, M.K.; Da Fonseca, I.I.M.; Miraldo, A.C.; Scattone, N.V.; Guerra, J.L.; Xavier, J.G.; Santos, M.; Gomes, C.O.M.D.S.; Ward, J.M.; et al. Inhibitory Effects of a Reengineered Anthrax Toxin on Canine Oral Mucosal Melanomas. Toxins 2020, 12, 157. [CrossRef] [PubMed]

16. Seban, R.-D.; Moya-Plana, A.; Antonios, L.; Yeh, R.; Marabelle, A.; Deutsch, E.; Schwartz, L.H.; Gómez, R.G.H.; Saenger, Y.; Robert, C.; et al. Prognostic 18F-FDG PET biomarkers in metastatic mucosal and cutaneous melanoma treated with immune checkpoint inhibitors targeting PD-1 and CTLA-4. Eur. J. Nucl. Med. Mol. Imaging 2020, 47, 2301-2312. [CrossRef] [PubMed]

17. Xu, X.; Palsgrove, D.; Kurian, E.; Yan, S.; Oliai, B.R.; Bishop, J.A. Variable Expression of S100 Protein in Sinonasal Malignant Mucosal Melanoma: A Potential Diagnostic Pitfall. Head Neck Pathol. 2020, 14, $929-935$. [CrossRef]

18. Kashyap, S.; Meel, R.; Singh, L.; Singh, M. Uveal melanoma. Semin. Diagn. Pathol. 2016, 33, $141-147$. [CrossRef]

19. Mitre, V.; Heym, K.; Clark, G.D.; Venkatramani, R. Neurocutaneous Melanocytosis and Leptomeningeal Melanoma. J. Pediatr. Hematol. 2019. [CrossRef]

20. Besra, K.; Panda, S.; Dash, S.; Samantaray, S.; Pathy, P.C.; Rout, N. Clinicopathological study of malignant melanoma in a regional cancer center. Indian J. Cancer 2018, 55, 292. [CrossRef]

21. Yde, S.S.; Sjoegren, P.; Heje, M.; Stolle, L.B. Mucosal Melanoma: A Literature Review. Curr. Oncol. Rep. 2018, 20, 28. [CrossRef]

22. Seetharamu, N.; Ott, P.A.; Pavlick, A.C. Mucosal Melanomas: A Case-Based Review of the Literature. Oncologist 2010, 15, 772-781. [CrossRef]

23. Spencer, K.R.; Mehnert, J.M. Mucosal Melanoma: Epidemiology, Biology and Treatment. Cancer Treat. Res. 2015, 167, 295-320. [CrossRef]

24. Chang, A.E.; Karnell, L.H.; Menck, H.R. The National Cancer Data Base report on cutaneous and noncutaneous melanoma: A summary of 84,836 cases from the past decade. The American College of Surgeons Commission on Cancer and the American Cancer Society. Cancer 1998, 83, 1664-1678. [CrossRef]

25. Patrick, R.J.; Fenske, N.A.; Messina, J.L. Primary mucosal melanoma. J. Am. Acad. Dermatol. 2007, 56, 828-834. [CrossRef] [PubMed]

26. Laver, N.V.; McLaughlin, M.E.; Duker, J.S. Ocular melanoma. Arch. Pathol. Lab. Med. 2010, 134, $1778-1784$. [PubMed]

27. Char, D.H. Ocular melanoma. Surg. Clin. N. Am. 2003, 83, 253-274. [CrossRef]

28. Da Costa, N.F.; Fernandes, N.C.; Borges, M.R.M.M. Study of the histopathological types of cutaneous melanoma in Palmas-TO from 2001 to 2011. An. Bras. de Dermatol. 2015, 90, 638-645. [CrossRef] [PubMed]

29. Amin, M.B.; Greene, F.L.; Edge, S.B.; Compton, C.C.; Gershenwald, J.E.; Brookland, R.K.; Meyer, L.; Gress, D.M.; Byrd, D.R.; Winchester, D.P. The Eighth Edition AJCC Cancer Staging Manual: Continuing to build a bridge from a population-based to a more "personalized" approach to cancer staging. CA Cancer J. Clin. 2017, 67, 93-99. [CrossRef] 
30. Guy, G.P.; Scolyer, R.A.; Hess, K.R.; Sondak, V.K.; Long, G.V.; Ross, M.I.; Lazar, A.J.; Faries, M.B.; Kirkwood, J.M.; McArthur, G.A.; et al. Melanoma staging: Evidence-based changes in the American Joint Committee on Cancer eighth edition cancer staging manual. CA Cancer J. Clin. 2017, 67, 472-492. [CrossRef]

31. Hahn, H.M.; Lee, K.G.; Choi, W.; Cheong, S.H.; Myung, K.B. An updated review of mucosal melanoma: Survival meta-analysis. Mol. Clin. Oncol. 2019, 11, 116-126. [CrossRef]

32. Han, A.Y.; Dhanjani, S.; Pettijohn, K.; Patel, P.B.; John, M.A.S. Optimal resection margin for head and neck cutaneous melanoma. Laryngoscope 2019, 129, 1386-1394. [CrossRef] [PubMed]

33. Cayrefourcq, L.; De Roeck, A.; Garcia, C.; Stoebner, P.-E.; Fichel, F.; Garima, F.; Perriard, F.; Daures, J.-P.; Meunier, L.; Alix-Panabières, C. S100-EPISPOT: A New Tool to Detect Viable Circulating Melanoma Cells. Cells 2019, 8, 755. [CrossRef] [PubMed]

34. Califf, R.M. Biomarker definitions and their applications. Exp. Biol. Med. 2018, 243, 213-221. [CrossRef] [PubMed]

35. Tandler, N.; Mosch, B.; Pietzsch, J. Protein and non-protein biomarkers in melanoma: A critical update. Amino Acids 2012, 43, 2203-2230. [CrossRef] [PubMed]

36. Belter, B.; Haase-Kohn, C.; Pietzsch, J. Biomarkers in Malignant Melanoma: Recent Trends and Critical Perspective. In Cutaneous Melanoma: Etiology and Therapy; Codon Publications: Brisbane, Australia, 2017; pp. 39-56.

37. Mandalà, M.; Merelli, B.; Massi, D. PD-L1 in melanoma: Facts and myths. Melanoma Manag. 2016, 3, $187-194$. [CrossRef] [PubMed]

38. Tsai, K.K.; Zarzoso, I.; Daud, A. PD-1 and PD-L1 antibodies for melanoma. Hum. Vaccines Immunother. 2014, 10, 3111-3116. [CrossRef] [PubMed]

39. Finck, S.J.; Giuliano, A.E.; Morton, D.L. LDH and melanoma. Cancer 1983, 51, 840-843. [CrossRef]

40. Petrelli, F.; Ardito, R.; Merelli, B.; Lonati, V.; Cabiddu, M.; Seghezzi, S.; Barni, S.; Ghidini, A. Prognostic and predictive role of elevated lactate dehydrogenase in patients with melanoma treated with immunotherapy and BRAF inhibitors: A systematic review and meta-analysis. Melanoma Res. 2019, 29, 1-12. [CrossRef]

41. Gray, M.R.; Martin del Campo, S.; Zhang, X.; Zhang, H.; Souza, F.F.; Carson, W.E., III; Smith, A.D. Metastatic melanoma: Lactate dehydrogenase levels and CT imaging findings of tumor devascularization allow accurate prediction of survival in patients treated with bevacizumab. Radiology 2014, 270, 425-434. [CrossRef]

42. Warburg, O. On respiratory impairment in cancer cells. Science 1956, 124, 269-270.

43. Palmer, S.R.; Erickson, L.A.; Ichetovkin, I.; Knauer, D.J.; Markovic, S.N. Circulating Serologic and Molecular Biomarkers in Malignant Melanoma. Mayo Clin. Proc. 2011, 86, 981-990. [CrossRef] [PubMed]

44. Alegre, E.; Sammamed, M.; Fernández-Landázuri, S.; Zubiri, L.; González, Á. Circulating Biomarkers in Malignant Melanoma. Int. Rev. Cytol. 2015, 69, 47-89. [CrossRef]

45. Petrelli, F.; Cabiddu, M.; Coinu, A.; Borgonovo, K.; Ghilardi, M.; Lonati, V.; Barni, S. Prognostic role of lactate dehydrogenase in solid tumors: A systematic review and meta-analysis of 76 studies. Acta Oncol. 2015, 54, 961-970. [CrossRef] [PubMed]

46. Kelderman, S.; Heemskerk, B.; Van Tinteren, H.; Brom, R.R.H.V.D.; Hospers, G.A.P.; Eertwegh, A.J.M.V.D.; Kapiteijn, E.W.; De Groot, J.W.B.; Soetekouw, P.; Jansen, R.L.; et al. Lactate dehydrogenase as a selection criterion for ipilimumab treatment in metastatic melanoma. Cancer Immunol. Immunother. 2014, 63, 449-458. [CrossRef] [PubMed]

47. Diem, S.; Kasenda, B.; Spain, L.; Martin-Liberal, J.; Marconcini, R.; Gore, M.; Larkin, J. Serum lactate dehydrogenase as an early marker for outcome in patients treated with anti-PD-1 therapy in metastatic melanoma. Br. J. Cancer 2016, 114, 256-261. [CrossRef]

48. Vereecken, P.; Cornélis, F.; Van Baren, N.; Vandersleyen, V.; Baurain, J.-F. A Synopsis of Serum Biomarkers in Cutaneous Melanoma Patients. Dermatol. Res. Pract. 2012, 2012, 1-7. [CrossRef]

49. Osella-Abate, S.; Savoia, P.; Quaglino, P.; Fierro, M.T.; Leporati, C.; Ortoncelli, M.; Bernengo, M.G. Tyrosinase expression in the peripheral blood of stage III melanoma patients is associated with a poor prognosis: A clinical follow-up study of 110 patients. Br. J. Cancer 2003, 89, 1457-1462. [CrossRef]

50. Quaglino, P.; Osella-Abate, S.; Cappello, N.; Ortoncelli, M.; Nardò, T.; Fierro, M.T.; Cavallo, F.; Savoia, P.; Bernengo, M.G. Prognostic relevance of baseline and sequential peripheral blood tyrosinase expression in 200 consecutive advanced metastatic melanoma patients. Melanoma Res. 2007, 17, 75-82. [CrossRef] 
51. Karagiannis, P.; Fittall, M.W.; Karagiannis, S.N. Evaluating biomarkers in melanoma. Front. Oncol. 2014, 4, 383. [CrossRef]

52. Cottrell, T.R.; Taube, J.M. PD-L1 and Emerging Biomarkers in Immune Checkpoint Blockade Therapy. Cancer J. 2018, 24, 41-46. [CrossRef]

53. Wu, X.; Gu, Z.; Chen, Y.; Chen, B.; Chen, W.; Weng, L.; Liu, X. Application of PD-1 Blockade in Cancer Immunotherapy. Comput. Struct. Biotechnol. J. 2019, 17, 661-674. [CrossRef] [PubMed]

54. Merelli, B.; Massi, D.; Cattaneo, L.; Mandalà, M. Targeting the PD1/PD-L1 axis in melanoma: Biological rationale, clinical challenges and opportunities. Crit. Rev. Oncol. 2014, 89, 140-165. [CrossRef] [PubMed]

55. Simeone, E.; Ascierto, P.A. Anti-PD-1 and PD-L1 antibodies in metastatic melanoma. Melanoma Manag. 2017, 4, 175-178. [CrossRef] [PubMed]

56. Zhou, J.; Mahoney, K.M.; Giobbie-Hurder, A.; Zhao, F.; Lee, S.; Liao, X.; Rodig, S.; Li, J.; Wu, X.; Butterfield, L.H.; et al. Soluble PD-L1 as a Biomarker in Malignant Melanoma Treated with Checkpoint Blockade. Cancer Immunol. Res. 2017, 5, 480-492. [CrossRef]

57. Madore, J.; Vilain, R.E.; Menzies, A.M.; Kakavand, H.; Wilmott, J.S.; Hyman, J.; Yearley, J.H.; Kefford, R.F.; Thompson, J.F.; Long, G.V.; et al. PD-L1 expression in melanoma shows marked heterogeneity within and between patients: Implications for anti-PD-1/PD-L1 clinical trials. Pigment. Cell Melanoma Res. 2014, 28, 245-253. [CrossRef]

58. Hutarew, G. PD-L1 testing, fit for routine evaluation? From a pathologist's point of view. Memo 2016, 9, 201-206. [CrossRef]

59. Kitano, S.; Nakayama, T.; Yamashita, M. Biomarkers for Immune Checkpoint Inhibitors in Melanoma. Front. Oncol. 2018, 8, 270. [CrossRef]

60. Donato, R.; Sorci, G.; Riuzzi, F.; Arcuri, C.; Bianchi, R.; Brozzi, F.; Tubaro, C.; Giambanco, I. S100B's double life: Intracellular regulator and extracellular signal. Biochim. et Biophys. Acta (BBA) Bioenerg. 2009, 1793, 1008-1022. [CrossRef]

61. Lin, J.; Yang, Q.; Wilder, P.T.; Carrier, F.; Weber, D.J. The Calcium-binding Protein S100B Down-regulates p53 and Apoptosis in Malignant Melanoma. J. Biol. Chem. 2010, 285, 27487-27498. [CrossRef]

62. Harpio, R.; Einarsson, R. S100 proteins as cancer biomarkers with focus on S100B in malignant melanoma. Clin. Biochem. 2004, 37, 512-518. [CrossRef]

63. Hauschild, A.; Engel, G.; Brenner, W.; Gläser, R.; Mönig, H.; Henze, E.; Christophers, E. S100B protein detection in serum is a significant prognostic factor in metastatic melanoma. Oncology 1999, 56, 338-344. [CrossRef] [PubMed]

64. Bouwhuis, M.; Suciu, S.; Kruit, W.; Sales, F.; Stoitchkov, K.; Patel, P.; Cocquyt, V.; Thomas, J.; Liénard, D.; Eggermont, A.M.; et al. Prognostic value of serial blood S100B determinations in stage IIB-III melanoma patients: A corollary study to EORTC trial 18952. Eur. J. Cancer 2011, 47, 361-368. [CrossRef] [PubMed]

65. Wagner, N.B.; Forschner, A.; Leiter, U.; Garbe, C.; Eigentler, T. S100B and LDH as early prognostic markers for response and overall survival in melanoma patients treated with anti-PD-1 or combined anti-PD-1 plus anti-CTLA-4 antibodies. Br. J. Cancer 2018, 119, 339-346. [CrossRef] [PubMed]

66. Shannan, B.; Perego, M.; Somasundaram, R.; Herlyn, M. Heterogeneity in Melanoma. Infect. Complicat. Cancer Patients 2015, 167, 1-15. [CrossRef]

67. Luke, J.J.; Flaherty, K.T.; Ribas, A.; Long, G.V. Targeted agents and immunotherapies: Optimizing outcomes in melanoma. Nat. Rev. Clin. Oncol. 2017, 14, 463-482. [CrossRef] [PubMed]

68. Hartman, R.I.; Lin, J.Y. Cutaneous Melanoma-A Review in Detection, Staging, and Management. Hematol. Clin. N. Am. 2019, 33, 25-38. [CrossRef]

69. Garbe, C.; Eigentler, T.K.; Keilholz, U.; Hauschild, A.; Kirkwood, J.M. Systematic Review of Medical Treatment in Melanoma: Current Status and Future Prospects. Oncologist 2011, 16, 5-24. [CrossRef]

70. Domingues, B.; Lopes, J.M.; Soares, P.; Pópulo, H. Melanoma treatment in review. ImmunoTargets Ther. 2018, 7, 35-49. [CrossRef]

71. Davies, N.; Bignell, G.R.; Cox, C.; Stephens, P.; Edkins, S.; Clegg, S.; Teague, J.W.; Woffendin, H.; Garnett, M.J.; Bottomley, W.; et al. Mutations of the BRAF gene in human cancer. Nature 2002, 417, 949-954. [CrossRef]

72. Wu, P.K.; Park, J.I. MEK1/2 inhibitors: Molecular activity and resistance mechanisms. Semin. Oncol. 2015, 42, 849-862. [CrossRef] 
73. Brugnara, S.; Sicher, M.; Bonandini, E.M.; Donner, D.; Chierichetti, F.; Barbareschi, M.; Girardelli, C.R.; Caffo, O. Treatment with combined dabrafenib and trametinib in BRAF(V600E)-mutated metastatic malignant melanoma: A case of long-term complete response after treatment cessation. Drugs Context 2018, 7, 212515. [PubMed]

74. Long, G.V.; Flaherty, K.T.; Stroyakovskiy, D.; Gogas, H.; Levchenko, E.; De Braud, F.; Larkin, J.; Garbe, C.; Jouary, T.; Hauschild, A.; et al. Dabrafenib plus trametinib versus dabrafenib monotherapy in patients with metastatic BRAF V600E/K-mutant melanoma: Long-term survival and safety analysis of a phase 3 study. Ann. Oncol. 2017, 28, 1631-1639. [CrossRef] [PubMed]

75. Chen, P.; Chen, F.; Zhou, B. Therapeutic efficacy and safety of combined BRAF and MEK inhibition in patients with malignant melanoma: A meta-analysis. OncoTargets Ther. 2017, 10, 5391-5403. [CrossRef] [PubMed]

76. Rizos, H.; Menzies, A.M.; Pupo, G.M.; Carlino, M.S.; Fung, C.; Hyman, J.; Haydu, L.E.; Mijatov, B.; Becker, T.M.; Boyd, S.C.; et al. BRAF Inhibitor Resistance Mechanisms in Metastatic Melanoma: Spectrum and Clinical Impact. Clin. Cancer Res. 2014, 20, 1965-1977. [CrossRef] [PubMed]

77. Herrscher, H.; Robert, C. Immune checkpoint inhibitors in melanoma in the metastatic, neoadjuvant, and adjuvant setting. Curr. Opin. Oncol. 2020, 32, 106-113. [CrossRef] [PubMed]

78. Robert, C.; Thomas, L.; Bondarenko, I.; O’Day, S.; Weber, J.; Garbe, C.; Lebbe, C.; Baurain, J.-F.; Testori, A.; Grob, J.-J.; et al. Ipilimumab plus Dacarbazine for Previously Untreated Metastatic Melanoma. N. Engl. J. Med. 2011, 364, 2517-2526. [CrossRef] [PubMed]

79. Sosman, J.A.; Kim, K.B.; Schuchter, L.; Gonzalez, R.; Pavlick, A.C.; Weber, J.S.; McArthur, G.A.; Hutson, T.E.; Moschos, S.J.; Flaherty, K.T.; et al. Survival in BRAF V600-Mutant Advanced Melanoma Treated with Vemurafenib. N. Engl. J. Med. 2012, 366, 707-714. [CrossRef]

80. Gutzmer, R.; Stroyakovskiy, D.; Gogas, H.; Robert, C.; Lewis, K.; Protsenko, S.; Pereira, R.P.; Eigentler, T.; Rutkowski, P.; Demidov, L.; et al. Atezolizumab, vemurafenib, and cobimetinib as first-line treatment for unresectable advanced BRAF(V600) mutation-positive melanoma (IMspire150): Primary analysis of the randomised, double-blind, placebo-controlled, phase 3 trial. Lancet 2020, 395, 1835-1844. [CrossRef]

81. Larkin, J.; Chiarion-Sileni, V.; Gonzalez, R.; Grob, J.-J.; Rutkowski, P.; Lao, C.D.; Cowey, C.L.; Schadendorf, D.; Wagstaff, J.; Dummer, R.; et al. Five-Year Survival with Combined Nivolumab and Ipilimumab in Advanced Melanoma. N. Engl. J. Med. 2019, 381, 1535-1546. [CrossRef]

82. Menzies, A.M.; Long, G.V. Dabrafenib and Trametinib, Alone and in Combination for BRAF-Mutant Metastatic Melanoma. Clin. Cancer Res. 2014, 20, 2035-2043. [CrossRef]

83. Robert, C.; Grob, J.J.; Stroyakovskiy, D.; Karaszewska, B.; Hauschild, A.; Levchenko, E.; Sileni, V.C.; Schachter, J.; Garbe, C.; Bondarenko, I.; et al. Five-Year Outcomes with Dabrafenib plus Trametinib in Metastatic Melanoma. N. Engl. J. Med. 2019, 381, 626-636. [CrossRef] [PubMed]

84. Dummer, R.; Ascierto, P.A.; Gogas, H.; Arance, A.; Mandalà, M.; Liszkay, G.; Garbe, C.; Schadendorf, D.; Krajsova, I.; Gutzmer, R.; et al. Encorafenib plus binimetinib versus vemurafenib or encorafenib in patients with BRAF-mutant melanoma (COLUMBUS): A multicentre, open-label, randomised phase 3 trial. Lancet Oncol. 2018, 19, 603-615. [CrossRef]

85. Robert, C.; Ribas, A.; Schachter, J.; Arance, A.; Grob, J.-J.; Mortier, L.; Daud, A.; Carlino, M.S.; McNeil, C.M.; Lotem, M.; et al. Pembrolizumab versus ipilimumab in advanced melanoma (KEYNOTE-006): Post-hoc 5-year results from an open-label, multicentre, randomised, controlled, phase 3 study. Lancet Oncol. 2019, 20 , 1239-1251. [CrossRef]

86. Sugaya, K.; Fukagawa, T.; Matsumoto, K.-I.; Mita, K.; Takahashi, E.-I.; Ando, A.; Inoko, H.; Ikemura, T. Three Genes in the Human MHC Class III Region near the Junction with the Class II: Gene for Receptor of Advanced Glycosylation End Products, PBX2 Homeobox Gene and a Notch Homolog, Human Counterpart of Mouse Mammary Tumor Gene int-3. Genomics 1994, 23, 408-419. [CrossRef]

87. Schmidt, A.M.; Stern, D.M. Receptor for age (RAGE) is a gene within the major histocompatibility class III region: Implications for host response mechanisms in homeostasis and chronic disease. Front. Biosci. 2001, 6, D1151-D1160. [PubMed]

88. Ostendorp, T.; Weibel, M.; Leclerc, E.; Kleinert, P.; Kroneck, P.M.; Heizmann, C.W.; Fritz, G. Expression and purification of the soluble isoform of human receptor for advanced glycation end products (sRAGE) from Pichia pastoris. Biochem. Biophys. Res. Commun. 2006, 347, 4-11. [CrossRef] [PubMed] 
89. Hubert, P.; Sawma, P.; Duneau, J.P.; Khao, J.; Hénin, J.; Bagnard, D.; Sturgis, J. Single-spanning transmembrane domains in cell growth and cell-cell interactions: More than meets the eye? Cell Adhes. Migr. 2010, 4, 313-324. [CrossRef]

90. Verweij, C.L. How RAGE turns in rage. Genes Immun. 2002, 3, 117-118. [CrossRef] [PubMed]

91. Wei, W.; Lampe, L.; Park, S.; Vangara, B.S.; Waldo, G.S.; Cabantous, S.; Subaran, S.S.; Yang, N.; Lakatta, E.G.; Lin, L. Disulfide Bonds within the C2 Domain of RAGE Play Key Roles in Its Dimerization and Biogenesis. PLOS ONE 2012, 7, e50736. [CrossRef]

92. Xue, J.; Manigrasso, M.; Scalabrin, M.; Rai, V.; Reverdatto, S.; Burz, D.S.; Fabris, D.; Schmidt, A.M.; Shekhtman, A. Change in the Molecular Dimension of a RAGE-Ligand Complex Triggers RAGE Signaling. Structure 2016, 24, 1509-1522. [CrossRef]

93. Neeper, M.; Schmidt, A.M.; Brett, J.; Yan, S.S.; Wang, F.; Pan, Y.C.; Elliston, K.; Stern, D.; Shaw, A. Cloning and expression of a cell surface receptor for advanced glycosylation end products of proteins. J. Biol. Chem. 1992, 267, 14998-15004. [PubMed]

94. Park, H.; Boyington, J.C. The $1.5 \AA$ Arystal Structure of Human Receptor for Advanced Glycation Endproducts (RAGE) Ectodomains Reveals Unique Features Determining Ligand Binding. J. Biol. Chem. 2010, 285, 40762-40770. [CrossRef] [PubMed]

95. Hofmann, M.A.; Drury, S.; Fu, C.; Qu, W.; Taguchi, A.; Lu, Y.; Avila, C.; Kambham, N.; Bierhaus, A.; Nawroth, P.; et al. RAGE mediates a novel proinflammatory axis: A central cell surface receptor for S100/calgranulin polypeptides. Cell 1999, 97, 889-901. [CrossRef]

96. Raucci, A.; Cugusi, S.; Antonelli, A.; Barabino, S.M.; Monti, L.; Bierhaus, A.; Reiss, K.; Saftig, P.; Bianchi, M.E. A soluble form of the receptor for advanced glycation endproducts (RAGE) is produced by proteolytic cleavage of the membrane-bound form by the sheddase a disintegrin and metalloprotease 10 (ADAM10). FASEB J. 2008, 22, 3716-3727. [CrossRef] [PubMed]

97. Galichet, A.; Weibel, M.; Heizmann, C.W. Calcium-regulated intramembrane proteolysis of the RAGE receptor. Biochem. Biophys. Res. Commun. 2008, 370, 1-5. [CrossRef]

98. Kalea, A.Z.; Reiniger, N.; Yang, H.; Arriero, M.; Schmidt, A.M.; Hudson, B.I. Alternative splicing of the murine receptor for advanced glycation end-products (RAGE) gene. FASEB J. 2009, 23, 1766-1774. [CrossRef] [PubMed]

99. Malherbe, P.; Richards, J.; Gaillard, H.; Thompson, A.; Diener, C.; Schuler, A.; Huber, G. cDNA cloning of a novel secreted isoform of the human receptor for advanced glycation end products and characterization of cells co-expressing cell-surface scavenger receptors and Swedish mutant amyloid precursor protein. Mol. Brain Res. 1999, 71, 159-170. [CrossRef]

100. Yonekura, H.; Yamamoto, Y.; Sakurai, S.; Petrova, R.G.; Abedin, J.; Li, H.; Yasui, K.; Takeuchi, M.; Makita, Z.; Takasawa, S.; et al. Novel splice variants of the receptor for advanced glycation end-products expressed in human vascular endothelial cells and pericytes, and their putative roles in diabetes-induced vascular injury. Biochem. J. 2003, 370, 1097-1109. [CrossRef]

101. Schlueter, C.; Hauke, S.; Flohr, A.M.; Rogalla, P.; Bullerdiek, J. Tissue-specific expression patterns of the RAGE receptor and its soluble forms-A result of regulated alternative splicing? Biochim. Biophys. Acta 2003, 1630, 1-6. [CrossRef]

102. Sterenczak, K.A.; Willenbrock, S.; Barann, M.; Klemke, M.; Soller, J.T.; Eberle, N.; Nolte, I.; Bullerdiek, J.; Escobar, H.M. Cloning, characterisation, and comparative quantitative expression analyses of receptor for advanced glycation end products (RAGE) transcript forms. Gene 2009, 434, 35-42. [CrossRef]

103. Jules, J.; Maiguel, D.; Hudson, B.I. Alternative Splicing of the RAGE Cytoplasmic Domain Regulates Cell Signaling and Function. PLoS ONE 2013, 8, e78267. [CrossRef] [PubMed]

104. Zong, H.; Madden, A.; Ward, M.; Mooney, M.H.; Elliott, C.T.; Stitt, A.W. Homodimerization Is Essential for the Receptor for Advanced Glycation End Products (RAGE)-mediated Signal Transduction. J. Biol. Chem. 2010, 285, 23137-23146. [CrossRef] [PubMed]

105. Ostendorp, T.; Leclerc, E.; Galichet, A.; Koch, M.; Demling, N.; Weigle, B.; Heizmann, C.W.; Kroneck, P.M.H.; Fritz, G. Structural and functional insights into RAGE activation by multimeric S100B. EMBO J. 2007, 26, 3868-3878. [CrossRef] [PubMed]

106. Xie, J.; Reverdatto, S.; Frolov, A.; Hoffmann, R.; Burz, D.S.; Shekhtman, A. Structural Basis for Pattern Recognition by the Receptor for Advanced Glycation End Products (RAGE). J. Biol. Chem. 2008, 283, 27255-27269. [CrossRef] [PubMed] 
107. Xue, J.; Rai, V.; Singer, D.; Chabierski, S.; Xie, J.; Reverdatto, S.; Burz, D.S.; Schmidt, A.M.; Hoffmann, R.; Shekhtman, A. Advanced Glycation End Product Recognition by the Receptor for AGEs. Structure 2011, 19, 722-732. [CrossRef] [PubMed]

108. Xu, D.; Young, J.H.; Krahn, J.M.; Song, D.; Corbett, K.D.; Chazin, W.J.; Pedersen, L.C.; Esko, J.D. Stable RAGE-Heparan Sulfate Complexes Are Essential for Signal Transduction. ACS Chem. Biol. 2013, 8, 1611-1620. [CrossRef] [PubMed]

109. Sitkiewicz, E.; Tarnowski, K.; Poznański, J.; Kulma, M.; Dadlez, M. Oligomerization Interface of RAGE Receptor Revealed by MS-Monitored Hydrogen Deuterium Exchange. PLoS ONE 2013, 8, e76353. [CrossRef]

110. Moysa, A.; Hammerschmid, D.; Szczepanowski, R.H.; Sobott, F.; Dadlez, M. Enhanced oligomerization of full-length RAGE by synergy of the interaction of its domains. Sci. Rep. 2019, 9, 1-15. [CrossRef]

111. Xie, J.; Burz, D.S.; He, W.; Bronstein, I.B.; Lednev, I.; Shekhtman, A. Hexameric Calgranulin C (S100A12) Binds to the Receptor for Advanced Glycated End Products (RAGE) Using Symmetric Hydrophobic Target-binding Patches. J. Biol. Chem. 2006, 282, 4218-4231. [CrossRef]

112. Yatime, L.; Andersen, G.R. Structural insights into the oligomerization mode of the human receptor for advanced glycation end-products. FEBS J. 2013, 280, 6556-6568. [CrossRef]

113. Koch, M.; Chitayat, S.; Dattilo, B.M.; Schiefner, A.; Diez, J.; Chazin, W.J.; Fritz, G. Structural Basis for Ligand Recognition and Activation of RAGE. Structure 2010, 18, 1342-1352. [CrossRef] [PubMed]

114. Sessa, L.; Gatti, E.; Zeni, F.; Antonelli, A.; Catucci, A.; Koch, M.; Pompilio, G.; Fritz, G.; Raucci, A.; Bianchi, M.E. The Receptor for Advanced Glycation End-Products (RAGE) Is Only Present in Mammals, and Belongs to a Family of Cell Adhesion Molecules (CAMs). PLoS ONE 2014, 9, e86903. [CrossRef] [PubMed]

115. Rani, S.G.; Sepuru, K.M.; Yu, C. Interaction of S100A13 with C2 domain of receptor for advanced glycation end products (RAGE). Biochim. Biophys. Acta (BBA) Proteins Proteom. 2014, 1844, 1718-1728. [CrossRef] [PubMed]

116. Sorci, G.; Riuzzi, F.; Giambanco, I.; Donato, R. RAGE in tissue homeostasis, repair and regeneration. Biochim. et Biophys. Acta (BBA) Bioenerg. 2013, 1833, 101-109. [CrossRef] [PubMed]

117. Riuzzi, F.; Sorci, G.; Sagheddu, R.; Chiappalupi, S.; Salvadori, L.; Donato, R. RAGE in the pathophysiology of skeletal muscle. J. Cachexia Sarcopenia Muscle 2018, 9, 1213-1234. [CrossRef]

118. Chellan, B.; Sutton, N.R.; Bowman, M.A.H. S100/RAGE-Mediated Inflammation and Modified Cholesterol Lipoproteins as Mediators of Osteoblastic Differentiation of Vascular Smooth Muscle Cells. Front. Cardiovasc. Med. 2018, 5, 163. [CrossRef] [PubMed]

119. Syed, A.; Zhu, Q.; Smith, E.A. Lateral diffusion and signaling of receptor for advanced glycation end-products (RAGE): A receptor involved in chronic inflammation. Eur. Biophys. J. 2017, 47, 39-48. [CrossRef]

120. Deng, X.; Sun, L.; Lai, X.; Xiang, L.; Li, Q.; Zhang, W.; Zhang, L.; Sun, S. Tea polypeptide ameliorates diabetic nephropathy through RAGE and NF-kB signaling pathway in type 2 diabetes mice. J. Agric. Food Chem. 2018, 66, 11957-11967. [CrossRef]

121. Hongwei, Y.; Ruiping, C.; Yingyan, F.; Guanjun, Z.; Jie, H.; Xingyu, L.; Jie, T.; Zhenghong, L.; Qin, G.; Junfeng, H.; et al. Effect of Irbesartan on AGEs-RAGE and MMPs systems in rat type 2 diabetes myocardial-fibrosis model. Exp. Biol. Med. 2019, 244, 612-620. [CrossRef]

122. Toth, C.; Martinez, J.; Zochodne, D.W. RAGE, Diabetes, and the Nervous System. Curr. Mol. Med. 2007, 7, 766-776. [CrossRef]

123. Ali, T.; Badshah, H.; Kim, T.H.; Kim, M.O. Melatonin attenuates D-galactose-induced memory impairment, neuroinflammation and neurodegeneration via RAGE/NF-K B/JNK signaling pathway in aging mouse model. J. Pineal Res. 2015, 58, 71-85. [CrossRef] [PubMed]

124. Gąsiorowski, K.; Brokos, B.; Echeverria, V.; Barreto, G.E.; Leszek, J. RAGE-TLR Crosstalk Sustains Chronic Inflammation in Neurodegeneration. Mol. Neurobiol. 2018, 55, 1463-1476. [CrossRef] [PubMed]

125. Ray, R.; Juranek, J.K.; Rai, V. RAGE axis in neuroinflammation, neurodegeneration and its emerging role in the pathogenesis of amyotrophic lateral sclerosis. Neurosci. Biobehav. Rev. 2016, 62, 48-55. [CrossRef] [PubMed]

126. Bangert, A.; Andrassy, M.; Müller, A.-M.; Bockstahler, M.; Fischer, A.; Volz, C.H.; Leib, C.; Göser, S.; Korkmaz-Icöz, S.; Zittrich, S.; et al. Critical role of RAGE and HMGB1 in inflammatory heart disease. Proc. Natl. Acad. Sci. USA 2016, 113, E155-E164. [CrossRef]

127. Fukami, K.; Yamagishi, S.-I.; Okuda, S. Role of AGEs-RAGE system in cardiovascular disease. Curr. Pharm. Des. 2014, 20, 2395-2402. [CrossRef] 
128. Lee, T.-W.; Kao, Y.-H.; Chen, Y.-J.; Chao, T.-F.; Lee, T.-W. Therapeutic potential of vitamin D in AGE/RAGE-related cardiovascular diseases. Cell. Mol. Life Sci. 2019, 76, 4103-4115. [CrossRef] [PubMed]

129. Li, J.; Wu, P.-W.; Zhou, Y.; Dai, B.; Zhang, P.-F.; Zhang, Y.-H.; Liu, Y.; Shi, X.-L. Rage induces hepatocellular carcinoma proliferation and sorafenib resistance by modulating autophagy. Cell Death Dis. 2018, 9, 1-10. [CrossRef]

130. Sims, G.P.; Rowe, D.C.; Rietdijk, S.T.; Herbst, R.; Coyle, A.J. HMGB1 and RAGE in Inflammation and Cancer. Annu. Rev. Immunol. 2010, 28, 367-388. [CrossRef]

131. Leclerc, E.; Vetter, S.W. The role of S100 proteins and their receptor RAGE in pancreatic cancer. Biochim. et Biophys. Acta (BBA) Mol. Basis Dis. 2015, 1852, 2706-2711. [CrossRef]

132. Sousa, M.M.; Du Yan, S.; Stern, D.; Saraiva, M.J. Interaction of the Receptor for Advanced Glycation End Products (RAGE) with Transthyretin Triggers Nuclear Transcription Factor kB (NF-kB) Activation. Lab. Investig. 2000, 80, 1101-1110. [CrossRef]

133. Chavakis, T.; Bierhaus, A.; Al-Fakhri, N.; Schneider, D.; Witte, S.; Linn, T.; Nagashima, M.; Morser, J.; Arnold, B.; Preissner, K.T.; et al. The pattern recognition receptor (RAGE) is a counterreceptor for leukocyte integrins: A novel pathway for inflammatory cell recruitment. J. Exp. Med. 2003, 198, 1507-1515. [CrossRef] [PubMed]

134. Ma, W.; Rai, V.; Hudson, B.I.; Song, F.; Schmidt, A.M.; Barile, G.R. RAGE binds C1q and enhances C1q-mediated phagocytosis. Cell. Immunol. 2012, 274, 72-82. [CrossRef] [PubMed]

135. Ruan, B.H.; Li, X.; Winkler, A.R.; Cunningham, K.M.; Kuai, J.; Greco, R.M.; Nocka, K.H.; Fitz, L.J.; Wright, J.F.; Pittman, D.D.; et al. Complement C3a, CpG Oligos, and DNA/C3a Complex Stimulate IFN- $\alpha$ Production in a Receptor for Advanced Glycation End Product-Dependent Manner. J. Immunol. 2010, 185, 4213-4222. [CrossRef] [PubMed]

136. Schmidt, A.-M.; Hofmann, M.; Taguchi, A.; Du Yan, S.; Stern, D.M. RAGE: A Multiligand Receptor Contributing to the Cellular Response in Diabetic Vasculopathy and Inflammation. Semin. Thromb. Hemost. 2000, 26, 485-494. [CrossRef] [PubMed]

137. Bierhaus, A.; Humpert, P.M.; Morcos, M.; Wendt, T.; Chavakis, T.; Arnold, B.; Stern, D.M.; Nawroth, P.P. Understanding RAGE, the receptor for advanced glycation end products. J. Mol. Med. 2005, 83, 876-886. [CrossRef]

138. Donato, R. Intracellular and extracellular roles of S100 proteins. Microsc. Res. Tech. 2003, 60, 540-551. [CrossRef]

139. Donato, R.; Cannon, B.R.; Sorci, G.; Riuzzi, F.; Hsu, K.; Weber, D.J.; Geczy, C.L. Functions of S100 proteins. Curr. Mol. Med. 2013, 13, 24-57. [CrossRef]

140. Salama, I.; Malone, P.; Mihaimeed, F.; Jones, J. A review of the S100 proteins in cancer. Eur. J. Surg. Oncol. (EJSO) 2008, 34, 357-364. [CrossRef]

141. Leclerc, E. The Roles of S100 Proteins and RAGE in Melanoma. In Breakthroughs in Melanoma Research; IntechOpen: London, UK, 2011; pp. 331-356.

142. Leclerc, E.; Fritz, G.; Weibel, M.; Heizmann, C.W.; Galichet, A. S100B and S100A6 Differentially Modulate Cell Survival by Interacting with Distinct RAGE (Receptor for Advanced Glycation End Products) Immunoglobulin Domains. J. Biol. Chem. 2007, 282, 31317-31331. [CrossRef]

143. Gaynor, R.; Irie, R.; Morton, D.; Herschman, H.R. S100 protein is present in cultured human malignant melanomas. Nat. Cell Biol. 1980, 286, 400-401. [CrossRef]

144. Xiong, T.-F.; Pan, F.-Q.; Li, D. Expression and clinical significance of S100 family genes in patients with melanoma. Melanoma Res. 2019, 29, 23-29. [CrossRef] [PubMed]

145. Karonidis, A.; Mantzourani, M.; Gogas, H.; Tsoutsos, D. Serum S100B levels correlate with stage, N status, mitotic rate and disease outcome in melanoma patients independent to LDH. J. B. U. ON. Off. J. Balk. Union Oncol. 2017, 22, 1296-1302.

146. Meghnani, V.; Wagh, A.; Indurthi, V.S.; Koladia, M.; Vetter, S.W.; Law, B.; Leclerc, E. The receptor for advanced glycation end products influences the expression of its S100 protein ligands in melanoma tumors. Int. J. Biochem. Cell Biol. 2014, 57, 54-62. [CrossRef]

147. Delphin, C.; Ronjat, M.; Deloulme, J.-C.; Garin, G.; Debussche, L.; Higashimoto, Y.; Sakaguchi, K.; Baudier, J. Calcium-dependent interaction of S100B with the C-terminal domain of the tumor suppressor p53. J. Biol. Chem. 1999, 274, 10539-10544. [CrossRef] 
148. Baudier, J.; Delphin, C.; Grunwald, D.; Khochbin, S.; Lawrence, J.J. Characterization of the tumor suppressor protein p53 as a protein kinase C substrate and a S100b-binding protein. Proc. Natl. Acad. Sci. USA 1992, 89, 11627-11631. [CrossRef] [PubMed]

149. Lin, J.; Blake, M.; Tang, C.; Zimmer, D.; Rustandi, R.R.; Weber, D.J.; Carrier, F. Inhibition of p53 Transcriptional Activity by the S100B Calcium-binding Protein. J. Biol. Chem. 2001, 276, 35037-35041. [CrossRef]

150. Keijser, S.; Missotten, G.S.; Bonfrer, J.M.; De Wolff-Rouendaal, D.; Jager, M.J.; De Keizer, R.J.W. Immunophenotypic markers to differentiate between benign and malignant melanocytic lesions. Br. J. Ophthalmol. 2006, 90, 213-217. [CrossRef]

151. Sviatoha, V.; Tani, E.; Kleina, R.; Sperga, M.; Skoog, L. Immunohistochemical analysis of the S100A1, S100B, CD44 and Bcl-2 antigens and the rate of cell proliferation assessed by Ki-67 antibody in benign and malignant melanocytic tumours. Melanoma Res. 2010, 20, 118-125. [CrossRef]

152. Leclerc, E. Measuring Binding of S100 Proteins to RAGE by Surface Plasmon Resonance. Adv. Struct. Saf. Stud. 2012, 963, 201-213. [CrossRef]

153. Jirku, M.; Lansky, Z.; Bednarova, L.; Sulc, M.; Monincova, L.; Majer, P.; Vyklický, L.; Vondrášek, J.; Teisinger, J.; Bousova, K.; et al. The characterization of a novel S100A1 binding site in the N-terminus of TRPM1. Int. J. Biochem. Cell Biol. 2016, 78, 186-193. [CrossRef]

154. Khan, I.; Yuan, T.; Chou, R.-H.; Yu, C. S100A4 inhibits cell proliferation by interfering with the S100A1-RAGE V domain. PLoS ONE 2019, 14, e0212299. [CrossRef] [PubMed]

155. Leclerc, E.; Heizmann, C.W.; Vetter, S.W. RAGE and S100 protein transcription levels are highly variable in human melanoma tumors and cells. Gen. Physiol. Biophys. 2009, 28, 28.

156. Maelandsmo, G.M.; Flørenes, V.A.; Mellingsaeter, T.; Hovig, E.; Kerbel, R.S.; Fodstad, O. Differential expression patterns of S100a2, S100a4 and S100a6 during progression of human malignant melanoma. Int. J. Cancer 1997, 74, 464-469. [CrossRef]

157. Nonaka, D.; Chiriboga, L.; Rubin, B.P. Differential expression of S100 protein subtypes in malignant melanoma, and benign and malignant peripheral nerve sheath tumors. J. Cutan. Pathol. 2008, 35, 1014-1019. [CrossRef]

158. Dahlmann, M.; Okhrimenko, A.; Marcinkowski, P.; Osterland, M.; Herrmann, P.; Smith, J.; Heizmann, C.W.; Schlag, P.M.; Stein, U. RAGE mediates S100A4-induced cell motility via MAPK/ERK and hypoxia signaling and is a prognostic biomarker for human colorectal cancer metastasis. Oncotarget 2014, 5, 3220-3233. [CrossRef]

159. Herwig, N.; Belter, B.; Wolf, S.; Haase-Kohn, C.; Pietzsch, J. Interaction of extracellular S100A4 with RAGE prompts prometastatic activation of A375 melanoma cells. J. Cell. Mol. Med. 2016, 20, 825-835. [CrossRef]

160. Ribé, A.; McNutt, N.S.; Rib, A. S100A6 Protein Expression is Different in Spitz Nevi and Melanomas. Mod. Pathol. 2003, 16, 505-511. [CrossRef]

161. Byström, S.; Fredolini, C.; Edqvist, P.-H.; Nyaiesh, E.-N.; Drobin, K.; Uhlen, M.; Bergqvist, M.; Ponten, F.; Schwenk, J.M. Affinity Proteomics Exploration of Melanoma Identifies Proteins in Serum with Associations to T-Stage and Recurrence. Transl. Oncol. 2017, 10, 385-395. [CrossRef]

162. Saha, A.; Lee, Y.-C.; Zhang, Z.; Chandra, G.; Su, S.-B.; Mukherjee, A.B. Lack of an Endogenous Anti-inflammatory Protein in Mice Enhances Colonization of B16F10 Melanoma Cells in the Lungs. J. Biol. Chem. 2010, 285, 10822-10831. [CrossRef]

163. Kinoshita, R.; Sato, H.; Yamauchi, A.; Takahashi, Y.; Inoue, Y.; Sumardika, I.W.; Chen, Y.; Tomonobu, N.; Araki, K.; Shien, K.; et al. exSSSRs (extracellular S100 soil sensor receptors)-Fc fusion proteins work as prominent decoys to S100A8/A9-induced lung tropic cancer metastasis. Int. J. Cancer 2019, 144, 3138-3145. [CrossRef]

164. Wagner, N.B.; Weide, B.; Gries, M.; Reith, M.; Tarnanidis, K.; Schuermans, V.; Kemper, C.; Kehrel, C.; Funder, A.; Lichtenberger, R.; et al. Tumor microenvironment-derived S100A8/A9 is a novel prognostic biomarker for advanced melanoma patients and during immunotherapy with anti-PD-1 antibodies. J. Immunother. Cancer 2019, 7, 343. [CrossRef] [PubMed]

165. Massi, D.; Landriscina, M.; Piscazzi, A.; Cosci, E.; Kirov, A.; Paglierani, M.; Di Serio, C.; Mourmouras, V.; Fumagalli, S.; Biagioli, M.; et al. S100A13 is a new angiogenic marker in human melanoma. Mod. Pathol. 2010, 23, 804-813. [CrossRef] [PubMed]

166. Landriscina, M.; Soldi, R.; Bagalá, C.; Micucci, I.; Bellum, S.; Tarantini, F.; Prudovsky, I.; Maciag, T. S100A13 participates in the release of fibroblast growth factor 1 in response to heat shock in vitro. J. Biol. Chem. 2001, 276, 22544-22552. [CrossRef] [PubMed] 
167. Azimi, A.; Pernemalm, M.; Stolt, M.F.; Hansson, J.; Lehtiö, J.; Brage, S.E.; Johansson, C.H. Proteomics analysis of melanoma metastases: Association between S100A13 expression and chemotherapy resistance. Br. J. Cancer 2014, 110, 2489-2495. [CrossRef] [PubMed]

168. Duan, J.-L.; Wang, J.-W.; Guan, Y.; Yin, Y.; Wei, G.; Cui, J.; Zhou, D.; Zhu, Y.-R.; Quan, W.; Xi, M.-M.; et al. Safflor yellow A protects neonatal rat cardiomyocytes against anoxia/reoxygenation injury in vitro. Acta Pharmacol. Sin. 2013, 34, 487-495. [CrossRef] [PubMed]

169. Zhu, L.; Ito, T.; Nakahara, T.; Nagae, K.; Fuyuno, Y.; Nakao, M.; Akahoshi, M.; Nakagawa, R.; Tu, Y.; Uchi, H.; et al. Upregulation of S100P, receptor for advanced glycation end products and ezrin in malignant melanoma. J. Dermatol. 2013, 40, 973-979. [CrossRef]

170. Tímár, J.; Udvarhelyi, N.; Bánfalvi, T.; Gilde, K.; Orosz, Z. Accuracy of the determination of S100B protein expression in malignant melanoma using polyclonal or monoclonal antibodies. Histopathology 2004, 44, 180-184. [CrossRef]

171. De Lecea, M.; Palomares, T.; Al Kassam, D.; Cavia-Saiz, M.; Geh, J.; De Llano, P.; Muñiz, P.; Armesto, D.; Martinez-Indart, L.; Alonso-Varona, A. Indoleamine 2,3 dioxygenase as a prognostic and follow-up marker in melanoma. A comparative study with LDH and S100B. J. Eur. Acad. Dermatol. Venereol. 2016, 31, 636-642. [CrossRef]

172. Gebhardt, C.; Lichtenberger, R.; Utikal, J. Biomarker value and pitfalls of serum S100B in the follow-up of high-risk melanoma patients. J. Dtsch. Dermatol. Ges. 2016, 14, 158-164. [CrossRef]

173. Meghnani, V.; Vetter, S.W.; Leclerc, E. RAGE overexpression confers a metastatic phenotype to the WM115 human primary melanoma cell line. Biochim. et Biophys. Acta (BBA) Mol. Basis Dis. 2014, 1842, 1017-1027. [CrossRef]

174. Guo, H.; Carlson, J.A.; Slominski, A.T. Role of TRPM in melanocytes and melanoma. Exp. Dermatol. 2012, 21, 650-654. [CrossRef]

175. Boye, K.; Maelandsmo, G.M. S100A4 and metastasis: A small actor playing many roles. Am. J. Pathol. 2010, 176, 528-535. [CrossRef] [PubMed]

176. Garrett, S.C.; Varney, K.M.; Weber, D.J.; Bresnick, A.R. S100A4, a Mediator of Metastasis. J. Biol. Chem. 2005, 281, 677-680. [CrossRef] [PubMed]

177. Fei, F.; Qu, J.; Zhang, S.; Li, Y.; Zhang, S. S100A4 in cancer progression and metastasis: A systematic review. Oncotarget 2017, 8, 73219-73239. [CrossRef] [PubMed]

178. Herwig, N.; Belter, B.; Pietzsch, J. Extracellular S100A4 affects endothelial cell integrity and stimulates transmigration of A375 melanoma cells. Biochem. Biophys. Res. Commun. 2016, 477, 963-969. [CrossRef] [PubMed]

179. Fullen, D.R.; Reed, J.A.; Finnerty, B.; McNutt, N.S. S100A6 expression in fibrohistiocytic lesions. J. Cutan. Pathol. 2001, 28, 229-234. [CrossRef] [PubMed]

180. Weterman, M.A.; Stoopen, G.M.; Van Muijen, G.N.; Kuznicki, J.; Ruiter, D.J.; Bloemers, H.P. Expression of calcyclin in human melanoma cell lines correlates with metastatic behavior in nude mice. Cancer Res. 1992, $52,1291-1296$.

181. Mitamura, Y.; Ito, T.; Nakano-Nakamura, M.; Uchi, H.; Furue, M. S100A6 and c-Kit-Positive Spindle Cell Melanoma of the Dorsal Foot. Case Rep. Dermatol. 2014, 6, 140-144. [CrossRef]

182. Bresnick, A.R.; Weber, D.J.; Zimmer, D.B. S100 proteins in cancer. Nat. Rev. Cancer 2015, 15, 96-109. [CrossRef]

183. Tomonobu, N.; Kinoshita, R.; Sakaguchi, M. S100 Soil Sensor Receptors and Molecular Targeting Therapy Against Them in Cancer Metastasis. Transl. Oncol. 2020, 13, 100753. [CrossRef]

184. Hibino, T.; Sakaguchi, M.; Miyamoto, S.; Yamamoto, M.; Motoyama, A.; Hosoi, J.; Shimokata, T.; Ito, T.; Tsuboi, R.; Huh, N.-H. S100A9 Is a Novel Ligand of EMMPRIN That Promotes Melanoma Metastasis. Cancer Res. 2013, 73, 172-183. [CrossRef] [PubMed]

185. Ruma, I.M.; Putranto, E.W.; Kondo, E.; Murata, H.; Watanabe, M.; Huang, P.; Kinoshita, R.; Futami, J.; Inoue, Y.; Yamauchi, A.; et al. MCAM, as a novel receptor for S100A8/A9, mediates progression of malignant melanoma through prominent activation of NF-kB and ROS formation upon ligand binding. Clin. Exp. Metastasis 2016, 33, 609-627. [CrossRef] [PubMed]

186. Chen, Y.; Sumardika, I.W.; Tomonobu, N.; Ruma, I.M.W.; Kinoshita, R.; Kondo, E.; Inoue, Y.; Sato, H.; Yamauchi, A.; Murata, H.; et al. Melanoma cell adhesion molecule is the driving force behind the dissemination of melanoma upon S100A8/A9 binding in the original skin lesion. Cancer Lett. 2019, 452, 178-190. [CrossRef] 
187. Jiang, H.; Hu, H.; Tong, X.; Jiang, Q.; Zhu, H.; Zhang, S.-Y. Calcium-binding protein S100P and cancer: Mechanisms and clinical relevance. J. Cancer Res. Clin. Oncol. 2011, 138, 1-9. [CrossRef]

188. Ilmonen, S.; Vaheri, A.; Asko-Seljavaara, S.; Carpén, O. Ezrin in primary cutaneous melanoma. Mod. Pathol. 2004, 18, 503-510. [CrossRef]

189. Mäkitie, T.; Carpén, O.; Vaheri, A.; Kivelä, T. Ezrin as a prognostic indicator and its relationship to tumor characteristics in uveal malignant melanoma. Investig. Ophthalmol. Vis. Sci. 2001, 42, 2442-2449.

190. Vicentino, A.R.R.; Carneiro, V.C.; Allonso, D.; Guilherme, R.D.F.; Benjamim, C.F.; Dos Santos, H.A.M.; Xavier, F.; Pyrrho, A.D.S.; Gomes, J.D.A.S.; Fonseca, M.D.C.; et al. Emerging Role of HMGB1 in the Pathogenesis of Schistosomiasis Liver Fibrosis. Front. Immunol. 2018, 9, 1979. [CrossRef]

191. Gerlitz, G.; Hock, R.; Ueda, T.; Bustin, M. The dynamics of HMG protein-chromatin interactions in living cells. Biochem. Cell Biol. 2009, 87, 127-137. [CrossRef]

192. Travers, A. Priming the nucleosome: A role for HMGB proteins? EMBO Rep. 2003, 4, 131-136. [CrossRef]

193. Goodwin, G.H.; Sanders, C.; Johns, E.W. A New Group of Chromatin-Associated Proteins with a High Content of Acidic and Basic Amino Acids. JBIC J. Biol. Inorg. Chem. 1973, 38, 14-19. [CrossRef]

194. Tang, D.; Kang, R.; Iii, H.J.Z.; Lotze, M.T. High-mobility group box 1 and cancer. Biochim. Biophys. Acta (BBA) Bioenerg. 2010, 1799, 131-140. [CrossRef]

195. Andersson, U.; Harris, H.E.; Yang, H.; Tracey, K.J. HMGB1 as a DNA-binding cytokine. J. Leukoc. Biol. 2002, 72, 1084-1091. [PubMed]

196. Ivanov, S.; Dragoi, A.M.; Wang, X.; Dallacosta, C.; Louten, J.; Musco, G.; Sitia, G.; Yap, G.S.; Wan, Y.; Biron, C.A.; et al. A novel role for HMGB1 in TLR9-mediated inflammatory responses to CpG-DNA. Blood 2007, 110, 1970-1981. [CrossRef]

197. Parkkinen, J.; Raulo, E.; Merenmies, J.; Nolo, R.; Kajander, E.O.; Baumann, M.; Rauvala, H. Amphoterin, the 30-kDa protein in a family of HMG1-type polypeptides. Enhanced expression in transformed cells, leading edge localization, and interactions with plasminogen activation. J. Biol. Chem. 1993, 268, 19726-19738. [PubMed]

198. Huttunen, H.J.; Rauvala, H. Amphoterin as an extracellular regulator of cell motility: From discovery to disease. J. Intern. Med. 2004, 255, 351-366. [CrossRef] [PubMed]

199. Riuzzi, F.; Sorci, G.; Donato, R. The Amphoterin (HMGB1)/Receptor for Advanced Glycation End Products (RAGE) Pair Modulates Myoblast Proliferation, Apoptosis, Adhesiveness, Migration, and Invasiveness. J. Biol. Chem. 2006, 281, 8242-8253. [CrossRef] [PubMed]

200. Todorova, J.; Pasheva, E. High mobility group B1 protein interacts with its receptor RAGE in tumor cells but not in normal tissues. Oncol. Lett. 2011, 3, 214-218. [CrossRef]

201. Sasahira, T.; Kirita, T.; Oue, N.; Bhawal, U.K.; Yamamoto, K.; Fujii, K.; Ohmori, H.; Luo, Y.; Yasui, W.; Bosserhoff, A.-K.; et al. High mobility group box-1-inducible melanoma inhibitory activity is associated with nodal metastasis and lymphangiogenesis in oral squamous cell carcinoma. Cancer Sci. 2008, 99, 1806-1812. [CrossRef]

202. Scaffidi, P.; Misteli, T.; Bianchi, M.E. Release of chromatin protein HMGB1 by necrotic cells triggers inflammation. Nat. Cell Biol. 2002, 418, 191-195. [CrossRef]

203. Huber, R.; Meier, B.; Otsuka, A.; Fenini, G.; Satoh, T.; Gehrke, S.; Widmer, D.; Levesque, M.P.; Mangana, J.; Kerl, K.; et al. Tumour hypoxia promotes melanoma growth and metastasis via High Mobility Group Box-1 and M2-like macrophages. Sci. Rep. 2016, 6, 29914. [CrossRef]

204. Hori, O.; Brett, J.; Slattery, T.; Cao, R.; Zhang, J.; Chen, J.X.; Nagashima, M.; Lundh, E.R.; Vijay, S.; Nitecki, D.; et al. The Receptor for Advanced Glycation End Products (RAGE) Is a Cellular Binding Site for Amphoterin: Mediation of neurite outgrowth and co-expression of rage and amphoterin in the developing nervous system. J. Biol. Chem. 1995, 270, 25752-25761. [CrossRef] [PubMed]

205. Li, W.; Xu, Q.; Deng, Y.; Yang, Z.; Xing, S.; Zhao, X.; Zhu, P.; Wang, X.; He, Z.; Gao, Y. High-mobility group box 1 accelerates lipopolysaccharide-induced lung fibroblast proliferation in vitro: Involvement of the NF- $\mathrm{kB}$ signaling pathway. Lab. Investig. 2015, 95, 635-647. [CrossRef] [PubMed]

206. Andersson, U.; Wang, H.; Palmblad, K.; Aveberger, A.-C.; Bloom, O.; Erlandsson-Harris, H.; Janson, A.; Kokkola, R.; Zhang, M.; Yang, H.; et al. High Mobility Group 1 Protein (Hmg-1) Stimulates Proinflammatory Cytokine Synthesis in Human Monocytes. J. Exp. Med. 2000, 192, 565-570. [CrossRef] [PubMed]

207. El Gazzar, M. HMGB1 modulates inflammatory responses in LPS-activated macrophages. Inflamm. Res. 2007, 56, 162-167. [CrossRef] 
208. Fages, C.; Nolo, R.; Huttunen, H.J.; Eskelinen, E.; Rauvala, H. Regulation of cell migration by amphoterin. J. Cell Sci. 2000, 113, 113.

209. Degryse, B.; Bonaldi, T.; Scaffidi, P.; Müller, S.; Resnati, M.; Sanvito, F.; Arrigoni, G.; Bianchi, M.E. The High Mobility Group (Hmg) Boxes of the Nuclear Protein Hmg1 Induce Chemotaxis and Cytoskeleton Reorganization in Rat Smooth Muscle Cells. J. Cell Biol. 2001, 152, 1197-1206. [CrossRef]

210. Tang, Q.; Li, J.; Zhu, H.; Li, P.; Zou, Z.; Xiao, Y. Hmgb1-IL-23-IL-17-IL-6-Stat3 Axis Promotes Tumor Growth in Murine Models of Melanoma. Mediat. Inflamm. 2013, 2013, 1-13. [CrossRef]

211. Zhang, K.; Anumanthan, G.; Scheaffer, S.; Cornelius, L.A. HMGB1/RAGE Mediates UVB-Induced Secretory Inflammatory Response and Resistance to Apoptosis in Human Melanocytes. J. Investig. Dermatol. 2019, 139, 202-212. [CrossRef]

212. Wang, W.; Chapman, N.M.; Zhang, B.; Li, M.; Fan, M.; Laribee, R.N.; Zaidi, M.R.; Pfeffer, L.M.; Chi, H.; Wu, Z.-H. Upregulation of PD-L1 via HMGB1-activated IRF3 and NF-kappaB contributes to UV radiation-induced immune suppression. Cancer Res. 2019, 79, 2909-2922. [CrossRef]

213. Nguyen, A.H.; Detty, S.Q.; Agrawal, D.K. Clinical Implications of High-mobility Group Box-1 (HMGB1) and the Receptor for Advanced Glycation End-products (RAGE) in Cutaneous Malignancy: A Systematic Review. Anticancer Res. 2017, 37, 1-8. [CrossRef]

214. Wu, C.-H.; Huang, S.-M.; Lin, J.-A.; Yen, G.-C. Inhibition of advanced glycation endproduct formation by foodstuffs. Food Funct. 2011, 2, 224-234. [CrossRef] [PubMed]

215. Singh, R.; Barden, A.; Mori, T.; Beilin, L. Advanced glycation end-products: A review. Diabetologia 2001, 44, 129-146. [CrossRef] [PubMed]

216. Wautier, M.P.; Guillausseau, P.-J.; Wautier, J.-L. Activation of the receptor for advanced glycation end products and consequences on health. Diabetes Metab. Syndr. Clin. Res. Rev. 2017, 11, 305-309. [CrossRef] [PubMed]

217. Zieman, S.J.; Kass, D.A. Advanced glycation endproduct crosslinking in the cardiovascular system: Potential therapeutic target for cardiovascular disease. Drugs 2004, 64, 459-470. [CrossRef] [PubMed]

218. Vetter, S.W. Glycated Serum Albumin and AGE Receptors. Adv. Clin. Chem. 2015, 72, 205-275. [CrossRef] [PubMed]

219. Abe, R.; Shimizu, T.; Sugawara, H.; Watanabe, H.; Nakamura, H.; Choei, H.; Sasaki, N.; Yamagishi, S.-I.; Shimizu, H.; Takeuchi, M. Regulation of Human Melanoma Growth and Metastasis by AGE-AGE Receptor Interactions. J. Investig. Dermatol. 2004, 122, 461-467. [CrossRef] [PubMed]

220. Yamagishi, S.-I.; Nakamura, K.; Inoue, H.; Kikuchi, S.; Takeuchi, M. Possible participation of advanced glycation end products in the pathogenesis of colorectal cancer in diabetic patients. Med. Hypotheses 2005, 64, 1208-1210. [CrossRef]

221. Nakamara, N.; Matsui, T.; Ishibashi, Y.; Sotokawauchi, A.; Fukami, K.; Higashimoto, Y.; Yamagishi, S.-I. RAGE-aptamer Attenuates the Growth and Liver Metastasis of Malignant Melanoma in Nude Mice. Mol. Med. 2017, 23, 295-306. [CrossRef]

222. Ojima, A.; Matsui, T.; Maeda, S.; Takeuchi, M.; Inoue, H.; Higashimoto, Y.; Yamagishi, S.-I. DNA aptamer raised against advanced glycation end products inhibits melanoma growth in nude mice. Lab. Investig. 2014, 94, 422-429. [CrossRef]

223. Yan, H.; Zhu, L.; Zhang, Z.; Li, H.; Li, P.; Wang, Y.; Leng, M. HMGB1-RAGE signaling pathway in pPROM. Taiwan. J. Obstet. Gynecol. 2018, 57, 211-216. [CrossRef]

224. Kwak, T.; Drews-Elger, K.; Ergonul, A.; Miller, P.C.; Braley, A.; Hwang, G.H.; Zhao, D.; Besser, A.; Yamamoto, Y.; El-Ashry, D.; et al. Targeting of RAGE-ligand signaling impairs breast cancer cell invasion and metastasis. Oncogene 2017, 36, 1559-1572. [CrossRef] [PubMed]

225. Yan, S.F.; Ramasamy, R.; Schmidt, A.M. Tempering the wrath of RAGE: An emerging therapeutic strategy against diabetic complications, neurodegeneration, and inflammation. Ann. Med. 2009, 41, 408-422. [CrossRef] [PubMed]

226. Srikanth, V.; Maczurek, A.; Phan, T.; Steele, M.; Westcott, B.; Juskiw, D.; Münch, G. Advanced glycation endproducts and their receptor RAGE in Alzheimer's disease. Neurobiol. Aging 2011, 32, 763-777. [CrossRef] [PubMed]

227. Logsdon, C.D.; Fuentes, M.K.; Huang, E.H.; Arumugam, T. RAGE and RAGE ligands in cancer. Curr. Mol. Med. 2007, 7, 777-789. [CrossRef]

228. Plotkin, L.I.; Essex, A.L.; Davis, H.M. RAGE Signaling in Skeletal Biology. Curr. Osteoporos. Rep. 2019, 17, 16-25. [CrossRef] 
229. Rojas, A.; Morales, M.; Gonzalez, I.; Araya, P. Inhibition of RAGE Axis Signaling: A Pharmacological Challenge. Curr. Drug Targets 2019, 20, 340-346. [CrossRef]

230. Huttunen, H.J.; Fages, C.; Rauvala, H. Receptor for advanced glycation end products (RAGE)-mediated neurite outgrowth and activation of NF-kappaB require the cytoplasmic domain of the receptor but different downstream signaling pathways. J. Biol. Chem. 1999, 274, 19919-19924. [CrossRef]

231. Kislinger, T.; Tanji, N.; Wendt, T.; Qu, W.; Lu, Y.; Ferran, L.J.; Taguchi, A.; Olson, K.; Bucciarelli, L.; Goova, M.; et al. Receptor for Advanced Glycation End Products Mediates Inflammation and Enhanced Expression of Tissue Factor in Vasculature of Diabetic Apolipoprotein E-Null Mice. Arter. Thromb. Vasc. Biol. 2001, 21, 905-910. [CrossRef]

232. Sakaguchi, T.; Yan, S.F.; Belov, D.; Rong, L.L.; Sousa, M.; Andrassy, M.; Marso, S.P.; Duda, S.; Arnold, B.; Liliensiek, B.; et al. Central role of RAGE-dependent neointimal expansion in arterial restenosis. J. Clin. Investig. 2003, 111, 959-972. [CrossRef]

233. Hudson, B.I.; Kalea, A.Z.; Arriero, M.D.M.; Harja, E.; Boulanger, E.; D’Agati, V.; Schmidt, A.M. Interaction of the RAGE Cytoplasmic Domain with Diaphanous-1 Is Required for Ligand-stimulated Cellular Migration through Activation of Rac1 and Cdc42. J. Biol. Chem. 2008, 283, 34457-34468. [CrossRef]

234. Sakaguchi, M.; Murata, H.; Yamamoto, K.-I.; Ono, T.; Sakaguchi, Y.; Motoyama, A.; Hibino, T.; Kataoka, K.; Huh, N.-H. TIRAP, an Adaptor Protein for TLR2/4, Transduces a Signal from RAGE Phosphorylated upon Ligand Binding. PLoS ONE 2011, 6, e23132. [CrossRef] [PubMed]

235. Molinie, N.; Gautreau, A. The Arp2/3 regulatory system and its deregulation in cancer. Physiol. Rev. 2018, 98, 215-238. [CrossRef]

236. Huang, J.-S.; Guh, J.-Y.; Chen, H.-C.; Hung, W.-C.; Lai, Y.-H.; Chuang, L.-Y. Role of receptor for advanced glycation end-product (RAGE) and the JAK/STAT-signaling pathway in AGE-induced collagen production in NRK-49F cells. J. Cell. Biochem. 2001, 81, 102-113. [CrossRef]

237. Kang, R.; Tang, D.; Lotze, M.T.; Zeh, I.H.J. AGER/RAGE-mediated autophagy promotes pancreatic tumorigenesis and bioenergetics through the IL6-pSTAT3 pathway. Autophagy 2012, 8, 989-991. [CrossRef]

238. Chen, J.; Jing, J.; Yu, S.; Song, M.; Tan, H.; Cui, B.; Huang, L. Advanced glycation endproducts induce apoptosis of endothelial progenitor cells by activating receptor RAGE and NADPH oxidase/JNK signaling axis. Am. J. Transl. Res. 2016, 8, 2169-2178. [PubMed]

239. Taguchi, A.; Blood, D.C.; Del Toro, G.; Canet, A.; Lee, D.C.; Qu, W.; Tanji, N.; Lu, Y.; Lalla, E.; Fu, C.; et al. Blockade of RAGE-amphoterin signalling suppresses tumour growth and metastases. Nat. Cell Biol. 2000, 405, 354-360. [CrossRef] [PubMed]

240. Kislinger, T.; Fu, C.; Huber, B.; Qu, W.; Taguchi, A.; Du Yan, S.; Hofmann, M.; Yan, S.F.; Pischetsrieder, M.; Stern, D.; et al. N(epsilon)-(carboxymethyl)lysine adducts of proteins are ligands for receptor for advanced glycation end products that activate cell signaling pathways and modulate gene expression. J. Biol. Chem. 1999, 274, 31740-31749. [CrossRef]

241. Lander, H.M.; Tauras, J.M.; Ogiste, J.S.; Hori, O.; Moss, R.A.; Schmidt, A.M. Activation of the Receptor for Advanced Glycation End Products Triggers a p21ras-dependent Mitogen-activated Protein Kinase Pathway Regulated by Oxidant Stress. J. Biol. Chem. 1997, 272, 17810-17814. [CrossRef]

242. Bianchi, R.; Giambanco, I.; Donato, R. S100B/RAGE-dependent activation of microglia via NF-kappa B and AP-1 Co-regulation of COX-2 expression by S100B, IL-1 beta and TNF-alpha. Neurobiol. Aging 2010, 31, 665-677. [CrossRef]

243. Huttunen, H.J.; Kuja-Panula, J.; Rauvala, H. Receptor for Advanced Glycation End Products (RAGE) Signaling Induces CREB-dependent Chromogranin Expression during Neuronal Differentiation. J. Biol. Chem. 2002, 277, 38635-38646. [CrossRef]

244. Tao, H.; Tang, T.; Wang, S.; Wang, Z.; Ma, Y.; Cai, T.; Cheng, X.; Qi, S.; Zhang, Y.; Qi, Z. The molecular mechanisms of Aloin induce gastric cancer cells apoptosis by targeting High Mobility Group Box 1. Drug Des. Dev. Ther. 2019, 13, 1221-1231. [CrossRef] [PubMed]

245. Hall, A. Rho GTPases and the control of cell behaviour. Biochem. Soc. Trans. 2005, 33 Pt 5, 891-895. [CrossRef]

246. Yamazaki, D.; Kurisu, S.; Takenawa, T. Involvement of Rac and Rho signaling in cancer cell motility in 3D substrates. Oncogene 2009, 28, 1570-1583. [CrossRef] [PubMed]

247. Medapati, M.R.; Dahlmann, M.; Ghavami, S.; Pathak, K.A.; Lucman, L.; Klonisch, T.; Hoang-Vu, C.; Stein, U.; Hombach-Klonisch, S. RAGE Mediates the Pro-Migratory Response of Extracellular S100A4 in Human Thyroid Cancer Cells. Thyroid 2015, 25, 514-527. [CrossRef] [PubMed] 
248. Fackler, O.T.; Grosse, R. Cell motility through plasma membrane blebbing. J. Cell Biol. 2008, 181, 879-884. [CrossRef] [PubMed]

249. Paluch, E.K.; Sykes, C.; Prost, J.; Bornens, M. Dynamic modes of the cortical actomyosin gel during cell locomotion and division. Trends Cell Biol. 2006, 16, 5-10. [CrossRef] [PubMed]

250. Wyckoff, J.B.; Pinner, S.E.; Gschmeissner, S.; Condeelis, J.S.; Sahai, E. ROCK- and Myosin-Dependent Matrix Deformation Enables Protease-Independent Tumor-Cell Invasion In Vivo. Curr. Biol. 2006, 16, 1515-1523. [CrossRef]

251. Rouhiainen, A.; Kuja-Panula, J.; Tumova, S.; Rauvala, H. RAGE-Mediated Cell Signaling. Adv. Struct. Saf. Stud. 2012, 963, 239-263. [CrossRef]

252. Oh, H.-N.; Seo, J.-H.; Lee, M.-H.; Yoon, G.; Cho, S.-S.; Liu, K.; Choi, H.; Oh, K.B.; Cho, Y.-S.; Kim, H.; et al. Oridonin induces apoptosis in oral squamous cell carcinoma probably through the generation of reactive oxygen species and the p38/JNK MAPK pathway. Int. J. Oncol. 2018, 52, 1749-1759. [CrossRef]

253. Wautier, M.-P.; Chappey, O.; Corda, S.; Stern, D.M.; Schmidt, A.M.; Wautier, J.-L. Activation of NADPH oxidase by AGE links oxidant stress to altered gene expression via RAGE. Am. J. Physiol. Metab. 2001, 280, E685-E694. [CrossRef]

254. Dukic-Stefanovic, S.; Gasic-Milenkovic, J.; Deuther-Conrad, W.; Münch, G. Signal transduction pathways in mouse microglia N-11 cells activated by advanced glycation endproducts (AGEs). J. Neurochem. 2003, 87, 44-55. [CrossRef] [PubMed]

255. Perrone, L.; Devi, T.S.; Hosoya, K.-I.; Terasaki, T.; Singh, L.P. Thioredoxin interacting protein (TXNIP) induces inflammation through chromatin modification in retinal capillary endothelial cells under diabetic conditions. J. Cell. Physiol. 2009, 221, 262-272. [CrossRef] [PubMed]

256. Sbai, O.; Devi, T.S.; Melone, M.A.B.; Féron, F.; Khrestchatisky, M.; Singh, L.P.; Perrone, L. RAGE-TXNIP axis is required for S100B-promoted Schwann cell migration, fibronectin expression and cytokine secretion. J. Cell Sci. 2010, 123, 4332-4339. [CrossRef] [PubMed]

257. Karin, M. NF-kappaB as a critical link between inflammation and cancer. Cold Spring Harb. Perspect. Biol. 2009, 1, a000141. [CrossRef] [PubMed]

258. Grimm, S.; Ott, C.; Hörlacher, M.; Weber, D.; Höhn, A.; Grune, T. Advanced-glycation-end-product-induced formation of immunoproteasomes: Involvement of RAGE and Jak2/STAT1. Biochem. J. 2012, 448, 127-139. [CrossRef] [PubMed]

259. Tang, C.H.; Keng, Y.T.; Liu, J.F. HMGB-1 induces cell motility and alpha 5 beta 1 integrin expression in human chondrosarcoma cells. Cancer Lett. 2012, 322, 98-106. [CrossRef]

260. Popa, I.; Ganea, E.; Petrescu, S.M. Expression and subcellular localization of RAGE in melanoma cells. Biochem. Cell Biol. 2014, 92, 127-136. [CrossRef]

261. Syed, D.N.; Aljohani, A.; Waseem, D.; Mukhtar, H. Ousting RAGE in melanoma: A viable therapeutic target? Semin. Cancer Biol. 2018, 49, 20-28. [CrossRef]

262. Nagy, J.A.; Chang, S.-H.; Dvorak, A.M.; Dvorak, H.F. Why are tumour blood vessels abnormal and why is it important to know? Br. J. Cancer 2009, 100, 865-869. [CrossRef]

263. Ito, N.; Demarco, R.A.; Mailliard, R.B.; Han, J.; Rabinowich, H.; Kalinski, P.; Stolz, N.B.; Zeh, H.J.; Lotze, M.T. Cytolytic cells induce HMGB1 release from melanoma cell lines. J. Leukoc. Biol. 2006, 81, 75-83. [CrossRef]

264. Treutiger, C.J.; Mullins, G.E.; Johansson, A.-S.M.; Rouhiainen, A.; Rauvala, H.M.E.; Erlandsson-Harris, H.; Andersson, U.; Yang, H.; Tracey, K.J.; Palmblad, J.E.W. High mobility group 1 B-box mediates activation of human endothelium. J. Intern. Med. 2003, 254, 375-385. [CrossRef] [PubMed]

265. Rojas, A.; Caveda, L.; Romay, C.; López, E.; Váldes, S.; Padrón, J.; Glaría, L.; Martínez, O.; Delgado, R. Effect of Advanced Glycosylation End Products on the Induction of Nitric Oxide Synthase in Murine Macrophages. Biochem. Biophys. Res. Commun. 1996, 225, 358-362. [CrossRef] [PubMed]

266. Wu, C.H.; Huang, C.M.; Lin, C.H.; Ho, Y.S.; Chen, C.M.; Lee, H.M. Advanced glycosylation end products induce NF-kappa B dependent NOS expression in RAW 264.7 cells. Mol. Cell. Endocrinol. 2002, 194, 9-17. [CrossRef]

267. Kokkola, R.; Andersson, A.; Mullins, G.; Ostberg, T.; Treutiger, C.J.; Arnold, B.; Nawroth, P.; Harris, R.A.; Harris, H.E. RAGE is the Major Receptor for the Proinflammatory Activity of HMGB1 in Rodent Macrophages. Scand. J. Immunol. 2005, 61, 1-9. [CrossRef]

268. Siveen, K.; Kuttan, G. Role of macrophages in tumour progression. Immunol. Lett. 2009, 123, 97-102. [CrossRef] 
269. Wild, C.A.; Bergmann, C.; Fritz, G.; Schuler, P.; Hoffmann, T.K.; Lotfi, R.; Westendorf, A.; Brandau, S.; Lang, S. HMGB1 conveys immunosuppressive characteristics on regulatory and conventional T cells. Int. Immunol. 2012, 24, 485-494. [CrossRef]

270. Wang, D.; Dubois, R.N. Immunosuppression associated with chronic inflammation in the tumor microenvironment. Carcinogenesis 2015, 36, 1085-1093. [CrossRef]

Publisher's Note: MDPI stays neutral with regard to jurisdictional claims in published maps and institutional affiliations.

(C) 2020 by the authors. Licensee MDPI, Basel, Switzerland. This article is an open access article distributed under the terms and conditions of the Creative Commons Attribution (CC BY) license (http://creativecommons.org/licenses/by/4.0/). 